\title{
Tracing the Nd isotope evolution of North Atlantic Deep and Intermediate Waters in the western North Atlantic since the Last Glacial Maximum from Blake Ridge sediments
}

\author{
M. Gutjahr ${ }^{1,2, *}$, M. Frank ${ }^{1,3}$, C. H. Stirling ${ }^{1,4}$, L. D. Keigwin ${ }^{5}$ and A. N. Halliday ${ }^{6}$ \\ ${ }^{1}$ ETH Zürich, Institute for Isotope Geochemistry and Mineral Resources, 8092 Zürich, Switzerland \\ ${ }^{2}$ now at: Bristol Isotope Group, Department of Earth Sciences, Wills Memorial Building, Bristol BS8 1RJ, \\ UK \\ ${ }^{3}$ now at: IfM-GEOMAR, Leibniz Institute for Marine Sciences at the University of Kiel, 24148 Kiel, \\ Germany \\ ${ }^{4}$ now at: Department of Chemistry, University of Otago, PO Box 56, Union Place, Dunedin, New Zealand \\ ${ }^{5}$ Woods Hole Oceanographic Institution, Woods Hole, MA 02543, U.S.A. \\ ${ }^{6}$ Department of Earth Sciences, University of Oxford, Oxford OX1 3PR, UK \\ ${ }^{*}$ Corresponding author: \\ Marcus Gutjahr \\ Department of Earth Sciences \\ Wills Memorial Building \\ Queens Road \\ Bristol BS8 1RJ \\ Tel.: +44 1179545235 \\ Email: Marcus.Gutjahr@bristol.ac.uk
}

Word count : 6,874 without abstract

Keywords: Neodymium, thermohaline circulation, NADW, GNAIW, last glacial maximum, sediment redistribution, ${ }^{230} \mathrm{Th}_{\mathrm{xs}}$ 


\begin{abstract}
A high-resolution authigenic $\mathrm{Nd}$ isotope record has been extracted from the Fe-Mn oxyhydroxide fraction of drift sediments along the Blake Ridge in the North Atlantic. These sediments facilitate reconstruction of the timing and extent of major hydrographic changes in the western North Atlantic since the Last Glacial Maximum (LGM). This is one of the few locations where sediments were deposited in the major flow path of the Western Boundary Undercurrent (WBUC), which transports North Atlantic Deep Water (NADW) southward at the present day. The hydrodynamic setting, however, also causes problems. Authigenic Nd isotope compositions similar to the typical present-day NADW $\varepsilon_{\mathrm{Nd}}$ value of $-13.5 \pm 0.5$ were only extracted from sediments located within the main water body of the WBUC coinciding with the highest along slope current velocity below $3200 \mathrm{~m}$ water depth. Above this depth the authigenic $\mathrm{Nd}$ isotopic composition is more radiogenic than measured in a nearby seawater profile and appears to be influenced by downslope and lateral sediment redistribution. Our data suggest that these radiogenic signals were formed at shallow depths in Florida current waters, compromising the recorded ambient deep water $\mathrm{Nd}$ isotope signal in the Blake Ridge Fe-Mn oxyhydroxide coatings from intermediate depths during the Holocene and the deglaciation.
\end{abstract}

The unradiogenic $\mathrm{Nd}$ isotopic composition typical of present-day NADW is not detectable along the Blake Ridge for any water depth during the LGM. Unlike the deglacial and Holocene sections, the intermediate core from $1790 \mathrm{~m}$ water depth did not experience significant sediment focussing during the LGM, in accord with the higher current velocities at this depth, suggesting that at this site an ambient LGM bottom water $\mathrm{Nd}$ isotope signal was recorded. Assuming this to be correct, our results indicate that the $\varepsilon_{\mathrm{Nd}}$ of the shallower glacial equivalent of NADW, the Glacial North Atlantic Intermediate Water (GNAIW) may have been as radiogenic as $-9.7 \pm 0.4$. Since the authigenic $\mathrm{Nd}$ isotope compositions of the Holocene and the deglacial sections of the intermediate depth sediment core were biased towards a shallow water signal, this first determination of a GNAIW $\varepsilon_{\mathrm{Nd}}$ for the LGM will have to be corroborated by results from other locations and archives. 
The LGM and deglacial sediments below $3400 \mathrm{~m}$ water depth bear no evidence of an ambient deep water $\varepsilon_{\mathrm{Nd}}$ as unradiogenic as -13.5. Although the deep core sites also experienced enhanced degrees of sediment focusing before the Younger Dryas, the $\varepsilon_{\mathrm{Nd}}$ values of between -11 and - 10 are more readily explained in terms of increased presence of Southern Source Waters. If this is the case, the change to $\mathrm{Nd}$ isotopic compositions that reflect a modern circulation pattern, including the presence of Lower NADW, only occurred after the Younger Dryas.

\section{Introduction}

Considerable research efforts has been expended on the reconstruction of past variability in the rate of meridional overturning circulation. A variety of proxies have been applied to better characterise past water mass distributions during the transition from the LGM to the Holocene, mostly based on nutrients $\left(\delta^{13} \mathrm{C}, \mathrm{Cd} / \mathrm{Ca}\right.$ ) (Boyle and Keigwin, 1987; Duplessy et al., 1988; Sarnthein et al., 1994; Marchitto et al., 2002; Curry and Oppo, 2005), oxygen isotopes of planktonic and benthic foraminifera (Labeyrie et al., 1992), water mass ${ }^{14} \mathrm{C}$ ventilation ages (Keigwin, 2004; Robinson et al., 2005), or ratios of water-borne radioactive trace metals such as ${ }^{231} \mathrm{~Pa}{ }^{230} \mathrm{Th}$ (McManus et al., 2004; Gherardi et al., 2005). Despite these efforts there are discrepancies regarding the evolution of the water mass structure in the North Atlantic as well as the timing of circulation changes since the Last Glacial Maximum (LGM). For example, whether modes of ocean circulation in the North Atlantic were the same during the Younger Dryas (YD) and the LGM is still unresolved (e.g., Duplessy et al., 1988; Labeyrie et al., 1992; Keigwin, 2004).

Today the Western Boundary Undercurrent (WBUC), which transports North Atlantic Deep Water (NADW) southward, is a composite water mass with contributions derived from various regions in the North Atlantic basin. Schematically, the Lower NADW (LNADW) is the mixing product of deep water derived from the Iceland-Scotland (NEADW) and the Irminger basins (NWADW), Labrador Sea Water and Subpolar Mode Water (SPMW) (Schmitz and McCartney, 1993). The Upper NADW (UNADW) in the 
western North Atlantic mainly consists of water derived from the Labrador Sea and SPMW (McCartney and Talley, 1982; Talley and McCartney, 1982; Schmitz and McCartney, 1993; Dickson and Brown, 1994; Schmitz, 1996). The presence of Antarctic Bottom Water (AABW) can be identified both in the deep eastern and western North Atlantic (Speer and McCartney, 1992; Schmitz and McCartney, 1993). There is consensus that Glacial North Atlantic Intermediate Water (GNAIW) replaced NADW during the LGM (Boyle and Keigwin, 1987; Keigwin, 2004; Curry and Oppo, 2005; Robinson et al., 2005; Lynch-Stieglitz et al., 2007). Convection of the GNAIW was shallower and water depths below 2000 to $2500 \mathrm{~m}$ were most likely dominated by northward advecting Southern Source Water (SSW). However, it is not clear whether GNAIW simply lacked the LNADW component or if the contributing water masses and flow path of GNAIW were entirely different from the Holocene situation. It is also not well constrained when the major hydrographic changes and the switch to modern circulation patterns occurred. For example, McManus et al. (2004) inferred relatively strong meridional overturning circulation (MOC) during the LGM followed by a near total collapse contemporaneous with catastrophic iceberg discharge event $\mathrm{H} 1$ and a rapid MOC resumption thereafter from the ${ }^{231} \mathrm{~Pa} /{ }^{230} \mathrm{Th}$ record of a sediment core on the Bermuda Rise in the North Atlantic. Furthermore, their data suggest that the MOC at its present-day mode of vigour was not attained before the beginning of the Holocene. Robinson et al. (2005) suggested brief episodes of deep ventilation in an otherwise dominantly shallowly-ventilated North Atlantic during the deglaciation. These authors did not find evidence for a complete shutdown of the MOC during H1 or any other time since the LGM. The radiocarbon record from deep-sea corals and paired benthicplanktonic foraminifera presented by Robinson et al. (2005) also indicated the presence of a radiocarbon-depleted intermediate depth water mass during $\mathrm{H} 1$ and the YD akin to modern Antarctic Intermediate Water (AAIW). Such a finding was also reported by Rickaby and Elderfield (2005) on the basis of $\mathrm{Cd} / \mathrm{Ca}$ in conjunction with $\delta^{13} \mathrm{C}$ in benthic foraminifera in a sediment core from the central North Atlantic south of Iceland. Their record indicated the presence of a nutrient-enriched intermediate depth water mass akin to AAIW during $\mathrm{H} 1$ and the YD, a hydrographic situation completely different from 
today. Hence, reconstructions of the hydrographic situation both during the LGM and the deglaciation are still controversial and far from resolved.

It has been demonstrated that $\mathrm{Nd}$ isotopes are a powerful proxy for past water mass structure and mixing, which led to inference of major circulation changes and weathering inputs in the past (Palmer and Elderfield, 1985; Reynolds et al., 1999; Vance and Burton, 1999; Frank et al., 2002; Scher and Martin, 2004). Neodymium has a residence time in the ocean of 600-2000 years (Jeandel et al., 1995; Tachikawa et al., 1999), which makes its isotopic composition a suitable quasi-conservative water mass tracer in the Atlantic Ocean in view of water mass residence times of only few 100 years. The dissolved ${ }^{143} \mathrm{Nd} /{ }^{144} \mathrm{Nd}$ in the ocean is a function of the flow path of a water mass (Frank, 2002; Goldstein and Hemming, 2003). In Precambrian crustal provinces the inherited $\mathrm{Nd}$ is very unradiogenic (low ${ }^{143} \mathrm{Nd} /{ }^{144} \mathrm{Nd}$ ), whereas young mantle-derived rocks display $\mathrm{Nd}$ isotope compositions that are highly radiogenic relative to the average Earth composition. Neodymium is dominantly supplied to the oceans via weathering of the continental crust through rivers, sub-glacial meltwater or leaching of shelf sediments to the adjacent ocean basins, and can in general only be subsequently modified by water mass mixing. The $\mathrm{Nd}$ isotope composition of dissolved $\mathrm{Nd}$ in river water generally matches that of the bulk source area (Goldstein and Jacobsen, 1987; Dahlqvist et al., 2005). Slight offsets have only been observed in glaciated terrains due to preferential weathering of certain mineral phases (Andersson et al., 2001; von Blanckenburg and Nägler, 2001). Particle-seawater interaction has also been suggested to be capable of modifying the $\mathrm{Nd}$ isotope composition of water masses (Tachikawa et al., 1999; Lacan and Jeandel, 2005a). For convenience the ${ }^{143} \mathrm{Nd} /{ }^{144} \mathrm{Nd}$ composition of a sample is generally normalised to the Chondrite Uniform Reservoir (CHUR) in epsilon notation:

$$
\varepsilon_{N d}=\left[\frac{{ }^{143} N d /{ }^{144} N d_{\text {sample }}}{{ }^{143} N d /{ }^{144} N d_{C H U R}}-1\right] \times 10^{4}
$$

$\left({ }^{143} \mathrm{Nd} /{ }^{144} \mathrm{Nd}_{\mathrm{CHUR}}=0.512638(\right.$ Jacobsen and Wasserburg, 1980) $)$. 
The $\mathrm{Nd}$ isotopic composition is a particularly powerful water mass tracer in the North Atlantic because, through admixtures from the Labrador Sea, NADW receives extremely unradiogenic $\mathrm{Nd}$ isotope compositions from weathering of Archean and Proterozoic continental crust in northern Canada and Greenland (Piepgras and Wasserburg, 1987; Lacan and Jeandel, 2005a). Lacan and Jeandel (2005a) suggested that, as the various proto-NADW water masses pass the Flemish Cape off Newfoundland, the NADW $\varepsilon_{\mathrm{Nd}}$ is already fairly homogeneous with an overall vertical variability of $1.3 \varepsilon_{\mathrm{Nd}}\left(-14.5 \leq \varepsilon_{\mathrm{Nd}} \leq\right.$ 13.2). Earlier work by Piepgras and Wasserburg (1987) indicated that in the vicinity of the Blake Ridge the $\varepsilon_{\mathrm{Nd}}$ of the Western Boundary Undercurrent (WBUC), which transports NADW southward, is fully homogenised at a value of $-13.5 \pm 0.5$. Other water masses in the Atlantic have more radiogenic Nd isotope compositions. Intermediate and deep waters in the Iceland, Norwegian and Greenland basins display $\varepsilon_{\mathrm{Nd}}$ on the order of 7.7 to -10.7 (Lacan and Jeandel, 2004), Mediterranean outflow water supplies an $\varepsilon_{\mathrm{Nd}}$ signature between -9.4 and -10.1 to the eastern Atlantic (Tachikawa et al., 2004), and Antarctic Intermediate and Bottom Waters in the Southern Atlantic are presently between -7 and -9 in $\varepsilon_{\mathrm{Nd}}$ (Jeandel, 1993).

In studies carried out in the Cape Basin in the South Atlantic Nd isotopes extracted from Fe-Mn oxyhydroxides in pelagic sediments were successfully applied to monitor changes in the past isotopic composition of Southern Ocean water masses, which were interpreted as changes in the strength of the export of NADW to the Southern Ocean on glacialinterglacial and millennial timescales (Rutberg et al., 2000; Piotrowski et al., 2004; 2005). It was concluded from positive shifts of up to $3 \varepsilon_{\mathrm{Nd}}$ units that the export of NADW into the Cape Basin was significantly reduced during the last glacial maximum and during the stadials of the last glacial stage between 60000 and 20000 years ago. However, these conclusions rely on the assumption that the $\mathrm{Nd}$ isotope composition of NADW and GNAIW have remained constant over the past $100 \mathrm{kyr}$. Recent studies provided overall support for this assumption from the $\mathrm{Nd}$ isotope composition of UNADW and its precursors (Foster and Vance, 2006; van de Flierdt et al., 2006; Foster et al., 2007), but none of these provided unambiguous constraints on short-term variations 
during extreme climatic conditions such as the LGM. Given the suggestion of a shutdown of deep water formation in the Labrador Sea during the LGM (de Vernal et al., 2002; Cottet-Puinel et al., 2004), the GNAIW Nd isotope composition during Marine Isotope Stage 2 (MIS 2) was likely different (more radiogenic) from NADW and GNAIW during MIS 1 and 3, respectively if changes in water mass contributions indeed occurred.

The aim of the present study is to reconstruct the Nd isotope evolution of NADW and GNAIW close to their site of formation between the LGM and today. We focus on the reconstruction of the water mass structure and the timing of hydrographic changes above the Blake Ridge in the western subtropical North Atlantic. This location is ideal for detecting past changes in southward water mass export because its sediments are located within the main flow path of the WBUC on the continental rise of eastern North America (Fig. 1). This study also highlights and discusses caveats in using the dispersed authigenic Fe-Mn oxyhydroxide fraction in marine drift sediment deposits from continental rise settings for water mass reconstructions.

\section{Material and Methods}

\section{Nd isotopes}

In order to obtain the present-day authigenic $\mathrm{Nd}$ isotope composition along the Blake Ridge, 22 core-top sediment samples from water depths between $775 \mathrm{~m}$ and $4712 \mathrm{~m}$, recovered during R/V Knorr cruise 140 (KNR140) were analysed (Fig. 1). Eight cores from the KNR140 cruise were selected for analyses of samples from the LGM. At three sites $(51 \mathrm{GGC}, 1780 \mathrm{~m} ; 31 \mathrm{GGC}, 3410 \mathrm{~m} ; 12 \mathrm{JPC}, 4250 \mathrm{~m})$ further downcore analyses were carried out. Additionally, the LGM sequence of ODP Leg 172, Site 1054A in 1300 $\mathrm{m}$ water depth was analysed. In general, bulk sediments were processed with the exception of the core-top samples, for which only the coarse fraction $>63 \mu \mathrm{m}$ was used. The extracted Fe-Mn oxyhydroxide $\mathrm{Nd}$ isotope signal from the bulk and the coarse fraction was found to be identical. 
The method applied for the extraction of seawater $\mathrm{Nd}$ isotopic compositions from Fe-Mn oxyhydroxide coatings was modified from a selection of existing sequential extraction methods (Chester and Hughes, 1967; Tessier et al., 1979; Rutberg et al., 2000; Bayon et al., 2002) and is summarised in a companion paper (Gutjahr et al., 2007). Carbonate was removed using a $\mathrm{Na}$ acetate buffer followed by removal of adsorbed metals using a $1 \mathrm{M}$ $\mathrm{MgCl}_{2}$ solution. Following three rinses in deionised water (Milli-Q system), the oxyhydroxide coatings were leached for three hours in a shaker at room temperature using a $0.05 \mathrm{M}$ hydroxylamine hydrochloride $(\mathrm{HH})-15 \%$ acetic acid $-0.03 \mathrm{M}$ Na-EDTA solution buffered to $\mathrm{pH} 4$ with analytical grade $\mathrm{NaOH}$. During initial stages of the study the Fe-Mn oxyhydroxide fractions were extracted using $0.5 \mathrm{M} \mathrm{HH}$ or, alternatively, using an oxalate cocktail (Tovar-Sanchez et al., 2003). This approach was also successful for extracting the seawater $\mathrm{Nd}$ fraction from sediments, but more dilute leaching solutions were found to be sufficiently efficient to dissolve the seawater fraction. For analyses of the radiogenic isotope composition of the remaining detrital fractions a second leach with the above HH-acetic acid-Na-EDTA leach was applied for 24 hours to ensure complete removal of residual Fe-Mn oxyhydroxide coatings. Additionally two rinses with deionised water were carried out prior to treatment of the samples with aqua regia for the destruction of organic matter. The remaining sediment was dissolved by pressure digestion in a concentrated $\mathrm{HF}-\mathrm{HNO}_{3}$ mixture. Separation and purification of $\mathrm{Nd}$ then followed standard procedures (Cohen et al., 1988). Total procedural blanks for $\mathrm{Nd}$ in the oxyhydroxide fraction were $<30 \mathrm{pg}$ and $315 \mathrm{pg}$ for the detrital fraction with all blanks being smaller than $1 \%$ of the total amount of $\mathrm{Nd}$ present in each sample.

Measurements of the Nd isotope compositions were carried out with a Nu Plasma MCICPMS at ETH Zürich. To correct for instrumental mass bias ${ }^{143} \mathrm{Nd} /{ }^{144} \mathrm{Nd}$ was normalised to a ${ }^{146} \mathrm{Nd} /{ }^{144} \mathrm{Nd}$ of 0.7219 . All $\mathrm{Nd}$ isotope results were normalised to a ${ }^{143} \mathrm{Nd} /{ }^{144} \mathrm{Nd}$ of 0.512115 for the JNdi-1 standard (Tanaka et al., 2000). The long-term reproducibility for repeated measurements of the JNdi-1 standard was $0.27 \varepsilon_{\mathrm{Nd}}(2 \sigma)$ over a period of 16 months $(\mathrm{n}=70)$. A set of six samples from deep core 12JPC were processed and measured at the University of Bristol, following the same extraction procedure as outlined above (denoted [a] in Table 4). These samples were measured on a Thermo Finnigan Neptune 
MC-ICPMS. Correction for the machine-induced mass bias for this set of additional samples followed Vance and Thirlwall (2002).

Depending on the composition of marine sediments, sequential leaching of a pure seawater-derived fraction can potentially prove difficult because of unwanted chemical extraction of other phases. In the case of reductive leaching of Fe-Mn oxyhydroxide coatings from marine sediments the detrital fraction might be partially attacked and alter the extracted $\mathrm{Nd}$ isotope signal of the coatings. In a companion paper (Gutjahr et al., 2007), we provide various lines of evidence for the reliability of the reductive chemical extraction procedure used here, including $\mathrm{Al} / \mathrm{Nd}$ ratios, $\mathrm{REE}$ patterns and mass balance calculations. According to these data, detrital contributions to the extracted signal are negligible and are clearly outweighed by the authigenic $\mathrm{Nd}$ fraction.

\section{${ }^{230} \mathrm{Th}_{\mathrm{xs}}$ and sediment redistribution}

For the ${ }^{230}$ Th-excess analyses bulk sediments were first treated with dilute $\mathrm{HNO}_{3}$ and dried down before the addition of a ${ }^{233} \mathrm{U} /{ }^{229} \mathrm{Th}$ spike. After pretreatment with aqua regia and complete digestion in a concentrated $\mathrm{HF}-\mathrm{HNO}_{3}$ mixture, Th and $\mathrm{U}$ were separated and purified following the method given by Luo et al. (1997). Total procedural blanks for ${ }^{232} \mathrm{Th}$ are $<10 \mathrm{pg}$ and $<15 \mathrm{pg}$ for ${ }^{238} \mathrm{U}$ and are negligible. Procedural blanks for ${ }^{230} \mathrm{Th}$ and ${ }^{234} \mathrm{U}$ were below the detection limit of the secondary electron multipliers (SEMs) on the $\mathrm{Nu}$ Plasma MC-ICPMS.

Due to the cup configuration of the MC-ICPMS used for the ${ }^{230} \mathrm{Th}_{\mathrm{xs}}$ analyses, individual measurements were split in two blocks to enable the measurement of the isotopes ${ }^{229} \mathrm{Th}$, ${ }^{230} \mathrm{Th},{ }^{233} \mathrm{U}$ and ${ }^{234} \mathrm{U}$ on two SEMs (Table 1). Using this configuration, the minor ${ }^{234} \mathrm{U}$ and ${ }^{230} \mathrm{Th}$ ion beams were monitored using IC0 and IC2 in the first analysis sequence, simultaneously with ${ }^{235} \mathrm{U}$ and ${ }^{238} \mathrm{U}$ on Faraday detectors, while ${ }^{233} \mathrm{U}$ and ${ }^{229} \mathrm{Th}$ were monitored subsequently, using the same multipliers, in a second analysis sequence (Table 1). The relative gain between the Faraday collectors and each SEM was calibrated against the CRM $145 \mathrm{U}$ standard solution (formerly NIST SRM 960) doped with a ${ }^{233} \mathrm{U} /{ }^{229} \mathrm{Th}$ 
spike. Instrumental mass bias of the Th isotope measurements was corrected for externally by normalising to ${ }^{238} \mathrm{U} /{ }^{235} \mathrm{U}$ of 137.88 (Steiger and Jager, 1977). Linearly interpolated half mass zeros were subtracted from small ion beams to account for peak tailing from the large beams of the major isotopes ${ }^{238} \mathrm{U}$ and ${ }^{232} \mathrm{Th}$. The concentration of seawater-derived (excess) ${ }^{230} \mathrm{Th}$ was then calculated by subtracting the amount of ${ }^{230} \mathrm{Th}$ in radioactive equilibrium with ${ }^{234} \mathrm{U}$ in the detrital fraction.

The flux of excess ${ }^{230} \mathrm{Th}$ was calculated as outlined in Francois et al. (2004). Subsequently, following Suman and Bacon (1989), a focusing factor $\Psi$ was determined, which is the ratio between the measured flux of ${ }^{230} \mathrm{Th}_{\mathrm{xs}}$ into the sediment and the expected ${ }^{230} \mathrm{Th}$ production rate in the overlying water column (i.e., $2.63 \mathrm{dpm} / \mathrm{m}^{3} * \mathrm{kyr}$ ):

$$
\psi=\frac{F\left({ }^{230} T h_{x s, \text { inital }}\right)}{P_{Z}}
$$

$P_{Z}$ refers to the ${ }^{230} \mathrm{Th}$ production rate from the decay of authigenic ${ }^{234} \mathrm{U}$ per water depth $z$. If no syndepositional sediment redistribution occurred then $\Psi=1$. If $\Psi>1$ this indicates additional lateral transport and deposition of sediment (focusing) and if sediment is lost through bottom currents (winnowing) this results in $\Psi<1 . \Psi>>1$ are commonly found in drift deposits (Suman and Bacon, 1989; Thomson et al., 1993). Focusing factors can only be determined between independently dated age tie points (Francois et al., 2004). The inherent potential error in the ${ }^{230} \mathrm{Th}$-normalised flux method is on the order of $30 \%$ at the highly dynamic location of the Blake Ridge, where advective transport of ${ }^{230} \mathrm{Th}$ has occurred. Individual results of the ${ }^{230} \mathrm{Th}_{\mathrm{xs}}$ measurements are displayed in Table 2.

The chronologies of the cores are based on published oxygen isotope stratigraphies displayed in Figures 4 and 5 (Keigwin, 2004). Published conventional ${ }^{14} \mathrm{C}$ ages (Keigwin, 2004; Robinson et al., 2005) were transformed into calendar years using the marine radiocarbon age calibration Marine04 of Hughen et al. (2004) assuming $\Delta \mathrm{R}=0$. 


\section{Results}

\subsection{Flow dynamics, sedimentation rates and focusing}

Today the flow of the WBUC is strongest along the lower Blake Outer Ridge between $3500 \mathrm{~m}$ and $4200 \mathrm{~m}$ water depth (Haskell and Johnson, 1993; Stahr and Sanford, 1999). Information on past modes of circulation at the Blake Ridge is scarce. Mean grain size analyses on various sediment cores carried out earlier (Haskell and Johnson, 1991) point to increased vigour of flow on the upper Blake Ridge during the deglaciation prior to 12 ka BP coinciding with reduced flow in the deeper parts. This pattern inverted after the YD. In cores below $2950 \mathrm{~m}$ water depth maximum mean grain sizes were recorded at ca. $10 \mathrm{ka}$ BP, indicating maximum vigour of flow along the deeper Blake Ridge during the early Holocene (Haskell and Johnson, 1991).

Sedimentation rates along the Blake Ridge varied systematically in response to the prevailing circulation patterns. Sedimentation rates at the site of 51GGC $(1790 \mathrm{~m})$ average $25.2 \mathrm{~cm} / \mathrm{kyr}$ over the past $9000 \mathrm{yrs}$ (Keigwin, 2004; see Table 2), whereas sediments in the deeper parts of the Blake Ridge accumulated at $\sim 4 \mathrm{~cm} / \mathrm{kyr}$ during the Holocene (Luo et al., 2001). During the LGM the inverse situation is observed with sedimentation rates of $6.3 \mathrm{~cm} / \mathrm{kyr}$ at shallow site $51 \mathrm{GGC}$ (Keigwin, 2004) and as high as $50 \mathrm{~cm} / \mathrm{kyr}$ at the deeper locations (Luo et al., 2001). The sedimentation rates in core 12JPC (4250 m) averaged to $24.1 \mathrm{~cm} / \mathrm{kyr}$ between the LGM and the YD, $\sim 7.0 \mathrm{~cm} / \mathrm{kyr}$ during the $\mathrm{YD}$ and $6.2 \mathrm{~cm} / \mathrm{kyr}$ during the Holocene.

This variability in sedimentation rates in different parts of the ridge reflects the nature of this drift deposit with changing loci of sediment winnowing and focusing. $\mathrm{The}^{230} \mathrm{Th}_{\mathrm{xs}}$ results indicate that during the LGM shallow core 51GGC experienced only little sediment focusing ( $\Psi=2.3$; sedimentation rate: $6.3 \mathrm{~cm} / \mathrm{kyr}$ ), which increased during the deglaciation ( $\Psi=4.1$ to 8.2 ; sed. rate: 9.5 to $22.3 \mathrm{~cm} / \mathrm{kyr}$ ) and reached maximum values during the Holocene (average $\Psi=15.7$; sed. rate averaging to $25.2 \mathrm{~cm} / \mathrm{kyr}$ ) (Fig. 2a, Table 2). Core CH88-11P in the lower segment of the Blake Outer Ridge, which was not 
a subject of this study (Fig. 1) reveals the opposite pattern with most prominent sediment focusing during the LGM ( $\Psi$ of ca. 7.8 ; sed. rate: $27.3 \mathrm{~cm} / \mathrm{kyr}$ ) (Fig. $2 \mathrm{~b}$ ), decreasing focusing during the deglaciation ( $\Psi$ of ca. 4.7 ; sed. rate: $16.6 \mathrm{~cm} / \mathrm{kyr}$ ) and only minor focusing during the Holocene ( $\Psi$ of ca. 1.9 ; sed. rate: $3.7 \mathrm{~cm} / \mathrm{kyr}$ ) (calculated from data in Luo et al. (2001). The overall spatial variability of sediment focusing was most likely a direct function of the high current speed at the respective depth of the WBUC (Haskell and Johnson, 1991; Haskell and Johnson, 1993), indicating that both sedimentation rates and the degree of sediment focusing were lowest within the main flow axis of the WBUC (cf. Biscaye and Anderson, 1994).

\subsection{Neodymium isotope results}

In Figure 3 the authigenic $\mathrm{Nd}$ isotope compositions extracted from the Fe-Mn oxyhydroxide coatings are shown for the present-day situation (Fig. 3a) and the LGM (Fig. 3b). Direct seawater data obtained by Piepgras and Wasserburg (1987) from nearby sites southeast of the Blake Ridge are displayed for comparison. During the Holocene the $\mathrm{Nd}$ isotope composition of coatings measured from sites below ca $3200 \mathrm{~m}$ have been very similar to the seawater data. This segment of the Blake Outer Ridge represents the zone of highest along slope velocity of the WBUC today (Stahr and Sanford, 1999). The lowest $\varepsilon_{\mathrm{Nd}}$ is observed at $4200 \mathrm{~m}$ ( $\varepsilon_{\mathrm{Nd}}$ of -13.5), coinciding with the highest WBUC speed observed by Haskell and Johnson (1993). Below $4200 \mathrm{~m}$ the $\mathrm{Nd}$ isotope compositions are again slightly more radiogenic ( $\varepsilon_{\mathrm{Nd}}=-12.5$ in $4712 \mathrm{~m}$ water depth), most likely reflecting the influence of AABW at the deepest sites (Stahr and Sanford, 1999). Above about 3200 $\mathrm{m}$ depth, the $\mathrm{Nd}$ isotope compositions define a systematic trend towards more radiogenic $\varepsilon_{\mathrm{Nd}}$ reaching highest values at $900 \mathrm{~m}$ water depth $\left(\varepsilon_{\mathrm{Nd}}=-8.7\right)$. During the LGM the unradiogenic $\mathrm{Nd}$ isotope signal characteristic of the present-day LNADW $\mathrm{Nd}$ isotope composition is not observable (Fig. 3b). Below $2200 \mathrm{~m}$ water depth the $\mathrm{Nd}$ isotope compositions have a very homogenous $\varepsilon_{\mathrm{Nd}}$ of $-10.5 \pm 0.3$. Above $2200 \mathrm{~m}$ water depth the LGM Nd isotopes were slightly more radiogenic with highest values of -9.5 at $1300 \mathrm{~m}$ water depth and are essentially indistinguishable from the Holocene data. 
Downcore Nd isotope results for two sites from the lower part of the Blake Ridge are illustrated in Figure 4 plotted against depth in core, spanning the interval from the LGM to the present. In core $31 \mathrm{GGC}$ the pre-Holocene $\mathrm{Nd}$ isotope composition was essentially constant $\left(\varepsilon_{\mathrm{Nd}}=-10.5 \pm 0.4\right.$, Fig. 4a). A significant switch to $\varepsilon_{\mathrm{Nd}}$ values of -13 , similar to present-day NADW occurred after the YD followed by a slight increase to an $\varepsilon_{\mathrm{Nd}}$ value of -12.2 today. In deepest core 12JPC the Nd isotope evolution between the LGM and the YD (12.9-11.5 ka BP) (Fig. 4b) appears somewhat more variable but the pattern is very similar to core $31 \mathrm{GGC}$. The major hydrographic switch to typical LNADW-like bottom water $\mathrm{Nd}$ isotope compositions $\left(\varepsilon_{\mathrm{Nd}} \sim-13.5 \pm 0.5\right)$ was recorded immediately after the YD. There appears to have been a slight increase during the Holocene towards the present-day authigenic $\varepsilon_{\mathrm{Nd}}$ value of -13.0. None of the sampled depths in the two cores recorded LNADW-like $\varepsilon_{\mathrm{Nd}}$ before the YD. In both cores minimum $\varepsilon_{\mathrm{Nd}}$ were recorded shortly after the YD.

The Nd isotope composition of the detrital fraction in the sediments was measured at three depths of core 12JPC (Fig. 4b). The detrital $\varepsilon_{\mathrm{Nd}}$ values have always been less radiogenic than the oxyhydroxide coatings and range from -12.2 in the LGM to -15.0 at 8.8 ka BP (Table 5).

Shallow site $51 \mathrm{GGC}$ from $1790 \mathrm{~m}$ water depth recorded completely different $\mathrm{Nd}$ isotope trends (Fig. 5). The Nd isotope compositions differ from direct seawater measurements (Piepgras and Wasserburg, 1987), as well as deglacial deep sea coral $\mathrm{Nd}$ isotope compositions (van de Flierdt et al., 2006). During the LGM only minor sediment focussing occurred ( $\Psi=2.3)$ and the authigenic Fe-Mn oxyhydroxide signal ranged from an $\varepsilon_{\mathrm{Nd}}$ of -9.5 to -10.1 . The sedimentary regime at this site changed from the deposition of coarse sand to silty sedimentation at the end of the LGM, and the time interval between 21 and $17.6 \mathrm{kyr}$ BP is not preserved. Silt directly overlying the LGM section was deposited at 17.2 ka BP, the authigenic Fe-Mn oxyhydroxide fraction being more than 1 $\varepsilon_{\mathrm{Nd}}$ less radiogenic than that in the LGM section. Compared with the LGM section the 
focusing factor in this early deglacial section increases significantly, contemporaneously with a drop in $\mathrm{Nd}$ isotope composition to an $\varepsilon_{\mathrm{Nd}}$ of -10.9 . The $\mathrm{Nd}$ isotope signal remained unchanged until the YD. During the following $2.5 \mathrm{kyr}$ (i.e., the YD and the transition to the Holocene) the largest Nd-isotopic change was recorded in the Fe-Mn oxyhydroxide coatings at this site with a shift of $1.7 \varepsilon_{\mathrm{Nd}}$ towards more radiogenic compositions, coinciding with a pronounced enhancement of sediment focusing. Subsequently, Nd isotope compositions became slightly less radiogenic again and the core-top sediments recorded an authigenic present-day $\varepsilon_{\mathrm{Nd}}$ of -10.3 . At this site the $\varepsilon_{\mathrm{Nd}}$ of the detrital fractions is more radiogenic than at the deeper site and varies between -12.4 during the deglaciation and -10.8 during the Holocene (Figs. 5, 6).

In Figure 6 the seawater Nd isotopic evolution of the intermediate core 51GGC in $1790 \mathrm{~m}$ water depth is directly compared with that of the deepest core 12JPC in $4250 \mathrm{~m}$ water depth. The similarity between core 12 JPC and 51GGC before the onset of the YD is apparent, as well as the switch to the presence of interglacial mode LNADW in core 12JPC after the YD (cf. Fig. 4b). In Figure 6 the switch towards $\varepsilon_{\mathrm{Nd}}$ similar to LNADW seems to have started already during the YD. We therefore want to point out that sedimentation rates during this time interval were low in core 12JPC $(\sim 7 \mathrm{~cm} / \mathrm{kyr})$, which may have led to the scavenging of the dissolved $\mathrm{Nd}$ in post-YD bottom water onto sediments of slightly older age (i.e., sediments dating back to the YD). The intermediate core in $1790 \mathrm{~m}$ does not show UNADW-typical $\varepsilon_{\mathrm{Nd}}$ at any time during MIS 2 and 1 . The isotopic compositions of detrital fractions in core 12JPC and 51GGC are also shown in Figure 6. Similar to the authigenic fraction, the detrital $\mathrm{Nd}$ isotope compositions did not vary significantly prior to the YD but diverged afterwards.

\section{Discussion}

\subsection{Present day authigenic Nd isotope compositions at the Blake Ridge}

Below 3200 m water depth the $\mathrm{Nd}$ isotope signal of Fe-Mn oxyhydroxide coatings match that of present-day seawater confirming LNADW presence along the deeper Blake Ridge 
today. Above the zone of highest along slope velocity of the WBUC the authigenic Nd isotope compositions obtained from the Fe-Mn oxyhydroxide coatings become systematically more radiogenic with decreasing water depth and deviate from direct seawater measurements from nearby water sampling sites (station OCE63 (Piepgras and Wasserburg, 1987)) by up to $4 \varepsilon_{\mathrm{Nd}}$ units in $1000 \mathrm{~m}$ water depth. Detrital contamination of the extracted seawater $\mathrm{Nd}$ isotope signal can be ruled out as a cause for this offset. Due to mass balance constraints unrealistically radiogenic $\mathrm{Nd}$ isotope compositions of the detrital fraction - even more radiogenic than present-day MORB - would be required to alter the $\mathrm{Nd}$ isotope signal to such an extreme extent (Gutjahr et al., 2007). The $\mathrm{Nd}$ isotope signal of the detrital fraction in all studied cores along the Blake Ridge, however, is always less radiogenic than that of the Fe-Mn oxyhydroxide phase (Figs. 4-6, Table 5).

Given that no water column $\mathrm{Nd}$ isotope data are available from directly above the Blake Ridge, it is possible, though unlikely, that the bottom water masses and corresponding isotope compositions along the Blake ridge have been significantly different from the open ocean profile studied at the OCE63 stations. This needs to be entertained as one possible way to interpret the data and could only be unambiguously disproved by future water column measurements in today's water column at the sediment - bottom water interface. Moreover, no study has yet been able to fully assess the importance of trace metal exchange processes in particle-laden bottom waters of western boundary undercurrents immediately above the seafloor.

The Nd isotope compositions presented in Figures 3 and 5 above $\sim 3200 \mathrm{~m}$ water depth are in conflict with direct seawater measurements published earlier (Piepgras and Wasserburg, 1987) but in very good agreement with dissolved and particulate Nd isotope compositions of nearby eastern North America (Goldstein and Jacobsen, 1987). Only North American shelf water has similar $\varepsilon_{\mathrm{Nd}}$ to seawater compositions recorded in Fe-Mn oxyhydroxide coatings at intermediate depths along the Blake Ridge. Therefore the question arises how such a shallow water signal was exported to abyssal depths. 
If the present-day water column $\mathrm{Nd}$ isotope signatures along the Blake Ridge are indeed truly represented by the OCE63 values (Piepgras and Wasserburg, 1987) in Figure 3a, then the observed offset recorded in the Fe-Mn oxyhydroxides above $3200 \mathrm{~m}$ water depth would support Lacan and Jeandel's suggestion of particle-seawater $\mathrm{Nd}$ isotope exchange through the boundary exchange mechanism at the continent-ocean interface. The only obvious mechanism to modify the characteristic Nd isotope composition of NADW along the flow path of the WBUC along eastern North America would be via sediment-seawater interaction along this continental rise. The average bulk crustal $\varepsilon_{\mathrm{Nd}}$ along eastern North America is -9 (Goldstein and Jacobsen, 1987) and thus such an alteration of the original NADW appears possible. A closer look at Table 5, Figures $4 \mathrm{~b}$ and 5 reveals, however, that $\varepsilon_{\mathrm{Nd}}$ of the detrital fraction in the sampled depths varies between -10.8 and -15.0 . The $\mathrm{Nd}$ isotope composition at any sampled depth is always less radiogenic than the Fe-Mn oxyhydroxide fraction in the respective depths. Therefore, it seems unlikely that boundary exchange has been the driving mechanism of altering the seawater values generating the observed $\mathrm{Nd}$ isotope pattern recorded in Fe-Mn oxyhydroxide coatings unless the signature had already been altered much further upstream.

\subsection{A plausible mechanism for the export of the shelf water signal}

The upper continental slope above the Blake Ridge is the location of a major water mass boundary (Figs. 1,7). To the west of the Blake Ridge on the Blake Plateau the vigorously flowing Gulf stream currently transports on average approximately $30 \mathrm{~Sv}$ of water derived from the Florida current northwards (Schmitz and McCartney, 1993; Reverdin et al., 2003). Interaction of Gulf stream water with near shore water masses is complex and variable, and leads to turbulence and re-suspension of sediments deposited on the shelf and upper continental slope (Eittreim et al., 1969; Eittreim et al., 1976; McCave, 1986; Biscaye et al., 1988). As the Gulf Stream passes the North American shelf edge towards the open Atlantic to the North of the Blake Ridge, re-suspended sediment from the shelf and upper continental slope is swept off the shelf towards the open Atlantic in a prominent intermediate depth nepheloid layer in the western North Atlantic (Eittreim et al., 1969; McCave, 1986; Biscaye et al., 1988). Significant amounts of redistributed 
sediment on the Blake Ridge have therefore most likely been derived from shallow shelf sites (Hunt et al., 1977; Biscaye et al., 1994). Because the major along slope flow axis of the WBUC is centred between $3500 \mathrm{~m}$ and $4200 \mathrm{~m}$ water depth, the bulk of the exported shelf and continental slope sediments were most likely deposited on the upper continental rise above the core of the WBUC, the vigor of which strongly controls the deposition of sediment (cf. Biscaye and Anderson, 1994).

During temporary storage on the shelf and prior to re-suspension, the sediments acquired a first generation of $\mathrm{Fe}-\mathrm{Mn}$ oxyhydroxide coatings incorporating the $\mathrm{Nd}$ isotope signature of the local shelf waters. When these sediments are exported downslope to the Blake Ridge and deposited at high sedimentation rates, this original surface water mass $\mathrm{Nd}$ isotope signal was also re-deposited and hence contributes to varying degrees to the extracted in situ deep water signals. The deeper the sampling sites along the Blake Ridge, the less prominent the shallow water bias in the Fe-Mn oxyhydroxide fraction. Original NADW Nd isotope compositions are attained in the core of the WBUC below $3200 \mathrm{~m}$, where fallout from the intermediate nepheloid layer has not been deposited due to the high current speed.

\subsection{Deep water Nd isotope evolution}

The highly unradiogenic $\mathrm{Nd}$ isotope signature below $3200 \mathrm{~m}$ water depth obtained from the Holocene Fe-Mn oxyhydroxide coatings in cores $31 \mathrm{GGC}$ and 12JPC (Fig. 4) was absent during the LGM (Fig. 3b, 4, 6). The authigenic $\varepsilon_{\mathrm{Nd}}$ in the cores along the Blake Ridge obviously reflects the presence of a water mass different from LNADW at the deeper Blake Ridge during the LGM. Various authors suggested a stronger presence of Southern Source Water (SSW) at depths below 2000 to $2500 \mathrm{~m}$ water depth in the glacial North Atlantic (Boyle and Keigwin, 1987; Labeyrie et al., 1992; Marchitto et al., 2002; Keigwin, 2004; Curry and Oppo, 2005; Robinson et al., 2005), which is consistent with the $\mathrm{Nd}$ isotope data. The observed $\varepsilon_{\mathrm{Nd}}$ signature of $-10.3 \pm 0.5$ may either suggest that glacial SSW, which was in the $\varepsilon_{\mathrm{Nd}}$ range of -6 to -9 in the Southern Atlantic (Jeandel, 1993; Rutberg et al., 2000; Piotrowski et al., 2004), had already been modified significantly by mixing with waters of North Atlantic origin by the time it reached the 
deeper Blake Ridge, unless the SSW $\varepsilon_{\mathrm{Nd}}$ during the LGM was less radiogenic than today. Alternatively, if the sediment re-mobilisation processes indicated by the ${ }^{230} \mathrm{Th}_{\mathrm{xs}}$, that affected the sampling sites at intermediate depth since the deglaciation were also operating at the deeper sites when LNADW was absent, then this might have biased the recorded ambient $\varepsilon_{\mathrm{Nd}}$ towards somewhat less radiogenic compositions. On the other hand, given that at present the original NADW Nd isotope signal in the Southern Atlantic is already modified towards more radiogenic $\varepsilon_{\mathrm{Nd}}$ (von Blanckenburg, 1999) it is also feasible to assume that such modification also occurred during the advection of SSW towards the deep North Atlantic during the LGM and the deglaciation, leading to a modification towards less radiogenic SSW $\varepsilon_{\mathrm{Nd}}$ in the North Atlantic. As soon as LNADW was ventilating the deeper Blake Ridge, its signal was recorded reliably in the Fe-Mn oxyhydroxide coatings in water depths below $\sim 3200 \mathrm{~m}$.

Figures 4 and 6 show that the $\varepsilon_{\mathrm{Nd}}$ of the water mass present at $4250 \mathrm{~m}$ at Blake Ridge during the LGM remained unchanged throughout the deglaciation until the YD. Core 31GGC from $3410 \mathrm{~m}$ water depth shows strikingly similar patterns but due to lower sampling resolution, any short-term excursions, as indicated by radiocarbon data (Robinson et al., 2005), are not resolved in our record. It can be resolved, however, that no major water mass change with a duration longer than a few hundred to a thousand years was recorded in the authigenic fraction of the sediments in $4250 \mathrm{~m}$ along the Blake Ridge until after the YD.

\subsection{The intermediate depth $\mathrm{Nd}$ isotope record}

It is not yet clear whether the $\mathrm{Nd}$ isotope composition of the GNAIW during the LGM was indeed identical to the interglacial mode UNADW $\varepsilon_{\mathrm{Nd}}$. During the LGM site $51 \mathrm{GGC}$ at $1790 \mathrm{~m}$ water depth was bathed in GNAIW (highlighted in Fig. 5) (Keigwin, 2004; Curry and Oppo, 2005). It is therefore important to evaluate the extracted $\mathrm{Nd}$ isotope signal during the LGM in terms of its paleoceanographic significance. Throughout the Holocene, the intermediate depth $\mathrm{Nd}$ isotope record was obviously compromised by 
preformed shallow water contributions to the extracted $\mathrm{Nd}$ isotope signal. We suggested in section 4.2 that the offset is caused by sediment redistribution processes that exported a shallow water $\mathrm{Nd}$ isotope signal further offshore, most likely to the North of the Blake Ridge. The ${ }^{230} \mathrm{Th}_{\mathrm{xs}}$ record from core $51 \mathrm{GGC}$ indicates intense sediment focusing during the Holocene, and pronounced focusing during the deglaciation. As the focusing factor $\Psi$ decreases through the deglaciation towards the LGM section, the $\mathrm{Nd}$ isotope compositions recorded in the Fe-Mn oxyhydroxide coatings of core 51GGC become systematically less radiogenic, and reproduce closer the reported deglacial UNADW composition presented by van de Flierdt et al. (2006). Sediment focusing is virtually absent during the LGM, however the $\mathrm{Nd}$ isotope composition is in excess of $1 \varepsilon_{\mathrm{Nd}}$ more radiogenic than the early deglacial section (average $\varepsilon_{\mathrm{Nd}} \approx-9.7$ ). This is an important finding: If sediment redistribution and focusing was the cause for the recorded offset seen in intermediate depth Fe-Mn oxyhydroxide coatings, then this mechanism was not operating during the LGM. Hence, if we have identified the offsetting process correctly, then the $\mathrm{Nd}$ isotope signature presented here for the intermediate water depth of $1790 \mathrm{~m}$ should reflect the true GNAIW Nd isotope signal (Fig. 5) at least during the LGM. During more than $4 \mathrm{kyr}$ the $\mathrm{Nd}$ isotope composition of the GNAIW, as recorded in FeMn oxyhydroxide coatings in core $51 \mathrm{GGC}$, remained relatively constant at an average $\varepsilon_{\mathrm{Nd}}$ of -9.8 . This is approximately 3.5 to $4 \varepsilon_{\mathrm{Nd}}$ different from interglacial NADW. The grain size of the sediment at this depth in the core is dominated by sand, indicating strong current velocities. The apparent average GNAIW $\left(\varepsilon_{\mathrm{Nd}} \approx-9.7\right)$ along the Blake Ridge suggests that waters circulating through the Labrador Sea did not contribute to the water mass signal recorded at the Blake Ridge. Even minor amounts of seawater derived from the Labrador Sea should have resulted in a significantly lower than observed $\varepsilon_{\mathrm{Nd}}$ along intermediate depths at the Blake Ridge.

It needs to be emphasized that since the $\mathrm{Nd}$ isotope record of the deglacial and the Holocene sections of core 51GGC have been compromised, the inferred GNAIW Nd isotope composition during the LGM has to be considered with some caution and preferably confirmed by studies from different locations and archives. Nonetheless, if the 
$\varepsilon_{\mathrm{Nd}}$ of GNAIW was as low as -13 during the LGM, it is unclear how it could have been completely removed by sediment redistribution processes. It is hard to envisage that the entire signal was removed laterally without leaving any trace from the intermediate depth of the core of GNAIW as well as downslope in the redeposited LGM sediments of the deeper cores. Hence, although controversial, our records suggest that water mass $\varepsilon_{\mathrm{Nd}}$ comparable to present-day compositions were absent at the Blake Ridge during the LGM. In the light of the reported deglacial UNADW Nd isotope compositions of van de Flierdt et al. (2006) and the laser ablation ferromanganese crust results of Foster et al. (2007) this radiogenic GNAIW Nd isotope signature could only have prevailed during MIS 2.

\subsection{Reduced export of NADW to the Southern Ocean during the LGM?}

A major conclusion of the high-resolution study of sediment core RC11-83 by Piotrowski et al. (2005) was a major decrease of glacial and stadial NADW export to the Cape Basin based on a shift of three $\varepsilon_{\mathrm{Nd}}$ units from -6.4 in the LGM to -9.3 during the Holocene. According to their estimations the fraction of the Pacific water component in CDW increased by approximately $50 \%$ relative to the Atlantic component during times of lowest NADW export (Piotrowski et al., 2005). If the $\mathrm{Nd}$ isotope compositions presented here indeed reflect the true GNAIW/NADW $\varepsilon_{\mathrm{Nd}}$ values during the LGM this estimate needs to be adjusted. Our data suggest that along the Blake Ridge the GNAIW during the LGM may have been as much as 3.5 to $4 \varepsilon_{\mathrm{Nd}}$ more radiogenic than interglacial UNADW, which then explains a significant part of the observed $\varepsilon_{\mathrm{Nd}}$ shift of CDW in the Cape Basin between the LGM and the Holocene without invoking changes in the export of NADW/GNAIW.

Based on $\mathrm{Nd}$ isotope compositions of seawater in the Drake Passage, Piepgras and Wasserburg (1982) estimated the Antarctic Circumpolar Deep Water (CDW) today to be composed of 50 to $70 \%$ Atlantic water. By maintaining this mixing ratio the change in GNAIW composition reported here can account for more than half of the observed glacial-interglacial $\varepsilon_{\mathrm{Nd}}$ variation of CDW in the Cape Basin (1.5 to $2.5 \varepsilon_{\mathrm{Nd}}$ ), but not for 
the entire shift published earlier (Piotrowski et al., 2004; 2005). A significant reduction of glacial NADW (GNAIW) export to the Southern Ocean is still required to generate the observed shift towards more Pacific-like glacial Nd isotope compositions of CDW in the Cape Basin, assuming that the $\mathrm{Nd}$ concentrations of the glacial water masses were the same as those observed today.

\section{Conclusions}

Our results highlight the limitations in applying sequential leaching procedures for past ambient deep water $\mathrm{Nd}$ isotope reconstructions from hydrographically complex continental rise settings. The chemical leaching procedure applied here for the extraction of past bottom water $\mathrm{Nd}$ isotope compositions from continental slope sediments can only extract an integrated authigenic $\mathrm{Nd}$ isotope signal, which in cases of pronounced sediment focusing may contain bottom water signatures from locations other than the final depositional site.

From core-top sediments along the Blake Ridge the original NADW $\mathrm{Nd}$ isotope composition can only be extracted reliably from Fe-Mn oxyhydroxide coatings of sediments from within the major flow axis of the WBUC. Above the major flow axis the extracted $\mathrm{Nd}$ isotope signal is increasingly offset towards a surface seawater $\mathrm{Nd}$ isotope signal from the North American shelf when compared with direct seawater measurements. This offset appears to be caused by the redistribution of dispersed shelf sediments laterally and downslope the Blake Ridge. Today a slight influence of Antarctic Bottom Water is observed in the Fe-Mn oxyhydroxide coating signals at the lowermost sites at $4700 \mathrm{~m}$ water depth along the Blake Ridge.

During the Last Glacial Maximum the Nd isotope composition of GNAIW, as extracted from Blake Ridge sediments, is about 3.5 to $4 \varepsilon_{\mathrm{Nd}}$ units higher than interglacial UNADW. Although similar to Holocene compositions $\left(\varepsilon_{\mathrm{Nd}}\right.$, GNAIW $\left.=-9.7 \pm 0.4\right)$, the glacial section at this site in $1790 \mathrm{~m}$ water depth was not affected by sediment focussing, as demonstrated by the ${ }^{230} \mathrm{Th}_{\mathrm{xs}}$ data. Therefore the $\mathrm{Nd}$ isotope compositions measured for the LGM section 
indeed seem to reflect the true ambient seawater composition at this water depth. According to our data, the distinctly unradiogenic $\mathrm{Nd}$ isotope composition typical of present-day NADW was not present at the Blake Ridge during the LGM at all. As a consequence, it is not likely that water derived from the Labrador Sea contributed significantly to GNAIW during the LGM. Because of the uncertainties regarding the reliability of the intermediate depth $\mathrm{Nd}$ isotope seawater record arising mainly from the sediment redistribution processes, our suggested GNAIW $\varepsilon_{\mathrm{Nd}}$ during the LGM has to be considered a preliminary finding that needs confirmation from future studies.

The $\mathrm{Nd}$ isotope compositions in sediment cores from water depths below $3400 \mathrm{~m}$ did not record the presence of typical LNADW until after the YD. These $\varepsilon_{\mathrm{Nd}}$ data suggest that the flow of the WBUC must have been restricted to the upper part of the Blake Ridge, and modern circulation was not initiated until after the YD.

\section{Acknowledgements}

M. B. Andersen, E.-K. Potter and M. Wipf are acknowledged for providing assistance with the Th separation and measurements. Tina van de Flierdt, Brian Haley, Sidney Hemming, Gavin Foster and Derek Vance are thanked for additional constructive suggestions. We are grateful to four anonymous reviewers who significantly improved the quality of the paper. Harry Elderfield is thanked for his thorough comments and editorial handling. 


\section{References}

Andersen, K.K., Azuma, N., Barnola, J.M., Bigler, M., Biscaye, P., Caillon, N., Chappellaz, J., Clausen, H.B., DahlJensen, D., Fischer, H., Fluckiger, J., Fritzsche, D., Fujii, Y., Goto-Azuma, K., Gronvold, K., Gundestrup, N.S., Hansson, M., Huber, C., Hvidberg, C.S., Johnsen, S.J., Jonsell, U., Jouzel, J., Kipfstuhl, S., Landais, A., Leuenberger, M., Lorrain, R., Masson-Delmotte, V., Miller, H., Motoyama, H., Narita, H., Popp, T., Rasmussen, S.O., Raynaud, D., Rothlisberger, R., Ruth, U., Samyn, D., Schwander, J., Shoji, H., Siggard-Andersen, M.L., Steffensen, J.P., Stocker, T., Sveinbjornsdottir, A.E., Svensson, A., Takata, M., Tison, J.L., Thorsteinsson, T., Watanabe, O., Wilhelms, F., White, J.W.C., 2004a. High-resolution record of Northern Hemisphere climate extending into the last interglacial period. Nature 431 (7005), 147151.

Andersen, M.B., Stirling, C.H., Potter, E.K., Halliday, A.N., 2004b. Toward epsilon levels of measurement precision on U-234/U-238 by using MC-ICPMS. Int. J. Mass Spectr. 237 (2-3), 107-118.

Andersson, P.S., Dahlqvist, R., Ingri, J., Gustafsson, O., 2001. The isotopic composition of $\mathrm{Nd}$ in a boreal river: A reflection of selective weathering and colloidal transport. Geochim. Cosmochim. Acta 65 (4), 521-527.

Bayon, G., German, C.R., Boella, R.M., Milton, J.A., Taylor, R.N., Nesbitt, R.W., 2002. An improved method for extracting marine sediment fractions and its application to $\mathrm{Sr}$ and Nd isotopic analysis. Chem. Geol. 187 (3-4), 179-199.

Biscaye, P.E., Anderson, R.F., 1994. Fluxes of particulate matter on the slope of the southern Middle Atlantic Bight - Seep-II. Deep-Sea Res. Part II 41 (2-3), 459-509.

Biscaye, P.E., Anderson, R.F., Deck, B.L., 1988. Fluxes of particles and constituents to the eastern United States continental slope and rise - Seep I. Cont. Shelf Res. 8 (5-7), 855-904.

Biscaye, P.E., Flagg, C.N., Falkowski, P.G., 1994. The Shelf Edge Exchange Processes experiment, SEEP-II - an introduction to hypotheses, results and conclusions. Deep-Sea Res. Part II 41 (2-3), 231-252.

Boyle, E.A., Keigwin, L.D., 1987. North Atlantic thermohaline circulation during the past 20,000 years linked to high-latitude surface temperature. Nature 330 (6143), 35-40.

Cheng, H., Edwards, R.L., Hoff, J., Gallup, C.D., Richards, D.A., Asmerom, Y., 2000. The half-lives of uranium-234 and thorium-230. Chem. Geol. 169 (1-2), 17-33.

Chester, R., Hughes, M.J., 1967. A chemical technique for the separation of ferromanganese minerals, carbonate minerals and adsorbed trace elements for pelagic sediments. Chem. Geol. 2, 249-262. 
Cohen, A.S., Onions, R.K., Siegenthaler, R., Griffin, W.L., 1988. Chronology of the pressure-temperature history recorded by a granulite terrain. Contr. Min. Petr. 98 (3), 303-311.

Cottet-Puinel, M., Weaver, A.J., Hillaire-Marcel, C., de Vernal, A., Clark, P.U., Eby, M., 2004. Variation of Labrador Sea Water formation over the Last Glacial cycle in a climate model of intermediate complexity. Quat. Sci. Rev. 23 (3-4), 449-465.

Curry, W.B., Oppo, D.W., 2005. Glacial water mass geometry and the distribution of delta $\mathrm{C}-13$ of Sigma $\mathrm{CO}_{2}$ in the western Atlantic Ocean. Paleoceanography 20 (1), Art. No. PA1017.

Dahlqvist, R., Andersson, P.S., Ingri, J., 2005. The concentration and isotopic composition of diffusible Nd in fresh and marine waters. Earth Planet. Sci. Letters 233 (1-2), 9-16.

de Vernal, A., Hillaire-Marcel, C., Peltier, W.R., Weaver, A.J., 2002. Structure of the upper water column in the northwest North Atlantic: Modern versus last glacial maximum conditions. Paleoceanography 17 (4), Art. No. 1050.

Dickson, R.R., Brown, J., 1994. The production of North Atlantic Deep Water - sources, rates, and pathways. J. Geophys. Res. - Oceans 99 (C6), 12319-12341.

Duplessy, J.C., Shackleton, N.J., Fairbanks, R.G., Labeyrie, L., Oppo, D.W., Kallell, N., 1988. Deep water source variations during the last climatic cycle and their impact on the global deep water circulation. Paleoceanography 3, 343-360.

Eittreim, S., Ewing, M., Thorndike, E.M., 1969. Suspended matter along continental margin of North American basin. Deep-Sea Res. 16 (6), 613-620.

Eittreim, S., Thorndike, E.M., Sullivan, L., 1976. Turbidity distribution in Atlantic Ocean. Deep-Sea Res. 23 (12), 1115-1127.

Foster, G.L., Vance, D., 2006. Negligible glacial-interglacial variation in continental chemical weathering rates. Nature 444 (7121), 918-921.

Foster, G.L., Vance, D., Prytulak, J., 2007. No change in the neodymium isotope composition of deep water exported from the North Atlantic on glacial-interglacial timescales. Geology 35 (1), 37-40.

Francois, R., Frank, M., van der Loeff, M.M.R., Bacon, M.P., 2004. Th-230 normalization: An essential tool for interpreting sedimentary fluxes during the late Quaternary. Paleoceanography 19 (1), Art. No. PA1018.

Frank, M., 2002. Radiogenic isotopes: Tracers of past ocean circulation and erosional input. Rev. Geophys. 40 (1), Art. No. 1001. 
Frank, M., Whiteley, N., Kasten, S., Hein, J.R., O'Nions, R.K., 2002. North Atlantic Deep Water export to the Southern Ocean over the past 14 Myr: Evidence from Nd and $\mathrm{Pb}$ isotopes in ferromanganese crusts. Paleoceanography 17 (2), Art. No. 1022.

Gherardi, J.M., Labeyrie, L., McManus, J.F., Francois, R., Skinner, L.C., Cortijo, E., 2005. Evidence from the Northeastern Atlantic basin for variability in the rate of the meridional overturning circulation through the last deglaciation. Earth Planet. Sci. Letters $240(3-4), 710-723$.

Goldstein, S.J., Jacobsen, S.B., 1987. The Nd and Sr isotopic systematics of river-water dissolved material - implications for the sources of $\mathrm{Nd}$ and $\mathrm{Sr}$ in seawater. Chem. Geol. 66 (3-4), 245-272.

Goldstein, S.L., Hemming, S.R., 2003. Long-lived isotopic tracers in oceanography, paleoceanography, and ice-sheet dynamics. Treatise on Geochemistry 6, 453-489.

Gutjahr, M., Frank, M., Stirling, C.H., Klemm, V., van de Flierdt, T., Halliday, A.N., 2007. Reliable extraction of a deepwater trace metal isotope signal from $\mathrm{Fe}-\mathrm{Mn}$ oxyhydroxide coatings of marine sediments. Chem. Geol. 242, 351-370.

Haskell, B.J., Johnson, T.C., 1991. Fluctuations in deep western North Atlantic circulation on the Blake Outer Ridge during the last deglaciation. Paleoceanography 6 , 21-31.

Haskell, B.J., Johnson, T.C., 1993. Surface sediment response to deep-water circulation on the Blake Outer Ridge, western North Atlantic - paleoceanographic implications. Sed. Geol. 82 (1-4), 133-144.

Holden, N.E., 1990. Total Half-Lives for Selected Nuclides. Pure and Applied Chemistry $62(5), 941-958$.

Hughen, K.A., Baillie, M.G.L., Bard, E., Beck, J.W., Bertrand, C.J.H., Blackwell, P.G., Buck, C.E., Burr, G.S., Cutler, K.B., Damon, P.E., Edwards, R.L., Fairbanks, R.G., Friedrich, M., Guilderson, T.P., Kromer, B., McCormac, G., Manning, S., Ramsey, C.B., Reimer, P.J., Reimer, R.W., Remmele, S., Southon, J.R., Stuiver, M., Talamo, S., Taylor, F.W., van der Plicht, J., Weyhenmeyer, C.E., 2004. Marine04 marine radiocarbon age calibration, 0-26 cal kyr BP. Radiocarbon 46, 1059-1086.

Hunt, R.E., Swift, D.J.P., Palmer, H., 1977. Constructional shelf topography, Diamond Shoals, North Carolina. Geol. Soc. Amer. Bull. 88 (2), 299-311.

Jacobsen, S.B., Wasserburg, G.J., 1980. Sm-Nd isotopic evolution of chondrites. Earth Planet. Sci. Letters 50 (1), 139-155.

Jeandel, C., 1993. Concentration and isotopic composition of Nd in the South Atlantic Ocean. Earth Planet. Sci. Letters 117 (3-4), 581-591. 
Jeandel, C., Bishop, J.K., Zindler, A., 1995. Exchange of neodymium and its isotopes between seawater and small and large particles in the Sargasso Sea. Geochim.

Cosmochim. Acta 59 (3), 535-547.

Keigwin, L.D., 2004. Radiocarbon and stable isotope constraints on Last Glacial Maximum and Younger Dryas ventilation in the western North Atlantic.

Paleoceanography 19 (4), Art. No. PA4012.

Labeyrie, L.D., Duplessy, J.C., Duprat, J., Juilletleclerc, A., Moyes, J., Michel, E., Kallel, N., Shackleton, N.J., 1992. Changes in the vertical structure of the North Atlantic ocean between glacial and modern times. Quat. Sci. Rev. 11 (4), 401-413.

Lacan, F., Jeandel, C., 2004. Neodymium isotopic composition and rare earth element concentrations in the deep and intermediate Nordic Seas: Constraints on the Iceland Scotland Overflow Water signature. Geochem. Geophys. Geosys. 5, Art. No. Q11006.

Lacan, F., Jeandel, C., 2005a. Acquisition of the neodymium isotopic composition of the North Atlantic Deep Water. Geochem. Geophys. Geosys. 6, Art. No. Q12008.

Lacan, F., Jeandel, C., 2005b. Neodymium isotopes as a new tool for quantifying exchange fluxes at the continent-ocean interface. Earth Planet. Sci. Letters 232 (3-4), 245-257.

Luo, S.D., Ku, T.L., Wang, L., Southon, J.R., Lund, S.P., Schwartz, M., 2001. Al-26, Be10 and U-Th isotopes in Blake Outer Ridge sediments: implications for past changes in boundary scavenging. Earth Planet. Sci. Letters 185 (1-2), 135-147.

Luo, X.Z., Rehkamper, M., Lee, D.C., Halliday, A.N., 1997. High precision Th-230/Th232 and U-234/U-238 measurements using energy-filtered ICP magnetic sector multiple collector mass spectrometry. Int. J. Mass Spectr. 171 (1-3), 105-117.

Lynch-Stieglitz, J., Adkins, J.F., Curry, W.B., Dokken, T., Hall, I.R., Herguera, J.C., Hirschi, J.J.M., Ivanova, E.V., Kissel, C., Marchal, O., Marchitto, T.M., McCave, I.N., McManus, J.F., Mulitza, S., Ninnemann, U., Peeters, F., Yu, E.-F., Zahn, R., 2007. Atlantic meridional overturning circulation during the Last Glacial Maximum. Science 316 (5821), 66-69.

Lynch-Stieglitz, J., Curry, W.B., Slowey, N., 1999. Weaker Gulf Stream in the Florida straits during the last glacial maximum. Nature 402 (6762), 644-648.

Marchitto, T.M., Oppo, D.W., Curry, W.B., 2002. Paired benthic foraminiferal Cd/Ca and $\mathrm{Zn} / \mathrm{Ca}$ evidence for a greatly increased presence of Southern Ocean Water in the glacial North Atlantic. Paleoceanography 17, Art. No. 1038.

McCartney, M.S., Talley, L.D., 1982. The sub-polar mode water of the North Atlantic ocean. J. Phys. Oceanography 12 (11), 1169-1188. 
McCave, I.N., 1986. Local and global aspects of the bottom nepheloid layers in the world ocean. Netherlands Journal of Sea Research 20 (2-3), 167-181.

McManus, J.F., Francois, R., Gherardi, J.M., Keigwin, L.D., Brown-Leger, S., 2004. Collapse and rapid resumption of Atlantic meridional circulation linked to deglacial climate changes. Nature 428 (6985), 834-837.

Palmer, M.R., Elderfield, H., 1985. Variations in the Nd isotopic composition of foraminifera from Atlantic Ocean sediments. Earth Planet. Sci. Letters 73 (2-4), 299-305.

Piepgras, D.J., Wasserburg, G.J., 1982. Isotopic composition of neodymium in waters from the Drake Passage. Science 217 (4556), 207-214.

Piepgras, D.J., Wasserburg, G.J., 1987. Rare earth element transport in the western North Atlantic inferred from Nd isotopic observations. Geochim. Cosmochim. Acta 51 (5), 1257-1271.

Piotrowski, A.M., Goldstein, S.L., Hemming, S.R., Fairbanks, R.G., 2004. Intensification and variability of ocean thermohaline circulation through the last deglaciation. Earth Planet. Sci. Letters 225 (1-2), 205-220.

Piotrowski, A.M., Goldstein, S.L., Hemming, S.R., Fairbanks, R.G., 2005. Temporal relationships of carbon cycling and ocean circulation at glacial boundaries. Science 307 (5717), 1933-1938.

Reverdin, G., Niiler, P.P., Valdimarsson, H., 2003. North Atlantic Ocean surface currents. J. Geophys. Res. - Oceans 108 (C1), Art. No. 3002.

Reynolds, B.C., Frank, M., O'Nions, R.K., 1999. Nd- and Pb-isotope time series from Atlantic ferromanganese crusts: implications for changes in provenance and paleocirculation over the last 8 Myr. Earth Planet. Sci. Letters 173 (4), 381-396.

Rickaby, R.E.M., Elderfield, H., 2005. Evidence from the high-latitude North Atlantic for variations in Antarctic Intermediate Water flow during the last deglaciation. Geochem. Geophys. Geosys. 6 Art. No. Q05001.

Robinson, L.F., Adkins, J.F., Keigwin, L.D., Southon, J., Fernandez, D.P., Wang, S.L., Scheirer, D.S., 2005. Radiocarbon variability in the western North Atlantic during the last deglaciation. Science 310 (5753), 1469-1473.

Rutberg, R.L., Hemming, S.R., Goldstein, S.L., 2000. Reduced North Atlantic Deep Water flux to the glacial Southern Ocean inferred from neodymium isotope ratios. Nature 405 (6789), 935-938.

Sarnthein, M., Winn, K., Jung, S.J.A., Duplessy, J.C., Labeyrie, L., Erlenkeuser, H., Ganssen, G., 1994. Changes in east Atlantic deep water circulation over the last 30,000 years - 8 time slice reconstructions. Paleoceanography 9, 209-267. 
Scher, H.D., Martin, E.E., 2004. Circulation in the Southern Ocean during the Paleogene inferred from neodymium isotopes. Earth Planet. Sci. Letters 228 (3-4), 391-405.

Schmitz, W.J., McCartney, M.S., 1993. On the North Atlantic circulation. Rev. Geophys. 31 (1), 29-49.

Schmitz, W.J.J., On the world ocean circulation, Vol. I, Woods Hole Oceanographic Institution, 1996, $148 \mathrm{pp}$.

Speer, K.G., McCartney, M.S., 1992. Bottom water circulation in the western North Atlantic. J. Phys. Oceanography 22 (1), 83-92.

Stahr, F.R., Sanford, T.B., 1999. Transport and bottom boundary layer observations of the North Atlantic Deep Western Boundary Current at the Blake Outer Ridge. Deep-Sea Res. Part II 46 (1-2), 205-243.

Steiger, R.H., Jager, E., 1977. Subcommission on geochronology: Convention on the use of decay constants in geo- and cosmochronology. Earth Planet. Sci. Letters 36 (3), 359362.

Suman, D.O., Bacon, M.P., 1989. Variations in Holocene sedimentation in the North American basin determined from Th-230 measurements. Deep-Sea Res. Part A 36 869878.

Tachikawa, K., Jeandel, C., Roy-Barman, M., 1999. A new approach to the Nd residence time in the ocean: the role of atmospheric inputs. Earth Planet. Sci. Letters 170 (4), 433446.

Tachikawa, K., Roy-Barman, M., Michard, A., Thouron, D., Yeghicheyan, D., Jeandel, C., 2004. Neodymium isotopes in the Mediterranean Sea: Comparison between seawater and sediment signals. Geochim. Cosmochim. Acta 68 (14), 3095-3106.

Talley, L.D., McCartney, M.S., 1982. Distribution and circulation of Labrador Sea Water. Journal of Physical Oceanography 12 (11), 1189-1205.

Tanaka, T., Togashi, S., Kamioka, H., Amakawa, H., Kagami, H., Hamamoto, T., Yuhara, M., Orihashi, Y., Yoneda, S., Shimizu, H., Kunimaru, T., Takahashi, K., Yanagi, T., Nakano, T., Fujimaki, H., Shinjo, R., Asahara, Y., Tanimizu, M., Dragusanu, C., 2000. JNdi-1: a neodymium isotopic reference in consistency with La Jolla neodymium. Chem. Geol. 168 (3-4), 279-281.

Tessier, A., Campbell, P.G.C., Bisson, M., 1979. Sequential extraction procedure for the speciation of particulate trace metals. Anal. Chem. 51 (7), 844-851.

Thomson, J., Colley, S., Anderson, R., Cook, G.T., Mackenzie, A.B., Harkness, D.D., 1993. Holocene sediment fluxes in the northeast Atlantic from Th-230 (excess) and radiocarbon measurements. Paleoceanography 8, 631-650. 
Tovar-Sanchez, A., Sanudo-Wilhelmy, S.A., Garcia-Vargas, M., Weaver, R.S., Popels, L.C., Hutchins, D.A., 2003. A trace metal clean reagent to remove surface-bound iron from marine phytoplankton. Mar. Chem. 82 (1-2), 91-99.

van de Flierdt, T., Robinson, L.F., Adkins, J.F., Hemming, S.R., Goldstein, S.J., 2006. Temporal stability of the neodymium isotope signature of the Holocene to glacial North Atlantic. Paleoceanography 21, Art. No. PA4102.

Vance, D., Burton, K., 1999. Neodymium isotopes in planktonic foraminifera: a record of the response of continental weathering and ocean circulation rates to climate change. Earth Planet. Sci. Letters 173 (4), 365-379.

Vance, D., Thirlwall, M., 2002. An assessment of mass discrimination in MC-ICPMS using Nd isotopes. Chem. Geol. 185 (3-4), 227-240.

von Blanckenburg, F., 1999. Perspectives: Paleoceanography - Tracing past ocean circulation? Science 286 (5446), 1862-1863.

von Blanckenburg, F., Nägler, T.F., 2001. Weathering versus circulation-controlled changes in radiogenic isotope tracer composition of the Labrador Sea and North Atlantic Deep Water. Paleoceanography 16 (4), 424-434. 


\section{Figure and Table Captions}

Figure 1. Study area along the Blake Ridge in the western North Atlantic. The Western Boundary Undercurrent passes the Blake Ridge southward centred between about 3500 and $4200 \mathrm{~m}$ water depth (Stahr and Sanford, 1999). The Florida Current transports Gulf Stream water on the Blake Plateau to the west of the Blake Ridge at water depths above about 700 m water depth (Lynch-Stieglitz et al., 1999). Black triangles represent core locations chosen for either core-top or LGM analyses. The three highlighted core sites represent locations for which $\mathrm{Nd}$ downcore analyses were carried out. Core location of CH88-11P studied by Luo et al. (2001) is also shown. Numbers in white boxes refer to sampling stations for seawater Nd isotope profile OCE63 (Piepgras and Wasserburg, 1987) plotted in Figure 3 (Station 1: 300 m; Station 2: 1000, 2200, 3400 m; Station 3: 50 m; Station 4: $4100 \mathrm{~m}$ water depth).

Figure 2. Focusing factor $\Psi$ for (a) core KNR140, Site $51 \mathrm{GGC}$ analysed for ${ }^{230} \mathrm{Th}_{\mathrm{xs}}$ activities in this study and (b) calculated for core CH88-11P analysed by Luo et al. (2001). The discontinuous records of the temporal evolution of the focusing factor arise from the fact that only average $\Psi$ can be determined between absolute age tie points (Francois et al., 2004). The shallow site experienced virtually no sediment focusing during the LGM and extreme focusing today, whereas the deep core reveals the opposite pattern. See text for discussion.

Figure 3. (a) Core-top authigenic $\mathrm{Nd}$ isotope signal as recorded in Fe-Mn oxyhydroxide coatings in sediments along the Blake Ridge. Schematic present-day water mass structure is taken from Stahr and Sanford (1999) (UNADW: Upper North Atlantic Deep Water; LNADW: Lower North Atlantic Deep Water; BW: Bottom Water, i.e. mixture between LNADW and Antarctic Bottom Water). Grey: Seawater measurements published by Piepgras and Wasserburg (1987) from station OCE63, located to the SSE of the Blake Ridge (see Fig. 1). (b) Authigenic Nd isotope signal during the LGM, measured on cores from nine different depths (open diamonds). Note that the prominent unradiogenic $\varepsilon_{\mathrm{Nd}}$ signature recorded in the core-top sediments below $2000 \mathrm{~m}$ is absent. The GNAIW 
ventilated depths between circa 1500 and $2000 \mathrm{~m}$ water depth. Individual Nd isotope data are presented in Table 3.

Figure 4. Downcore seawater $\mathrm{Nd}$ isotope results from this study and $\delta^{18} \mathrm{O}$ stratigraphy from Keigwin (2004) (sampled depths in $\delta^{18} \mathrm{O}$ plot are marked by red dots) for (a) core $31 \mathrm{GGC}$ in $3410 \mathrm{~m}$ and (b) 12JPC in $4250 \mathrm{~m}$ water depth along the deeper Blake Ridge. Average results are plotted for depths in core for which duplicate analyses were carried out, however individual results are also shown (yellow filled diamonds). Black circles represent $\mathrm{Nd}$ isotope compositions of the detrital fraction. The modern NADW $\varepsilon_{\mathrm{Nd}}$, as measured by Piepgras and Wasserburg (1987), is shown in grey box. Typical interglacial LNADW signatures were only recorded after the YD. Individual $\mathrm{Nd}$ isotope data are presented in Tables 4 and 5. Blue arrows in Fig. 4b indicate absolute age tie points published in Keigwin (2004) and Robinson et al. (2005).

Figure 5. Upper panel: $\delta^{18} \mathrm{O}$ stratigraphy from Keigwin (2004) (sampled depths in the $\delta^{18} \mathrm{O}$ plot are marked by red dots). Middle panel: ${ }^{230} \mathrm{Th}_{\mathrm{xs}}$ results as shown in Figure 2. The lower panel illustrates the $\mathrm{Nd}$ isotope evolution at site $51 \mathrm{GGC}$, as recorded by $\mathrm{Fe}-\mathrm{Mn}$ oxyhydroxide coatings. Average results are plotted for depths in core for which duplicate analyses were carried out but individual results are also shown (yellow filled diamonds). The Nd isotope compositions of the detrital fraction is always less radiogenic than the Fe$\mathrm{Mn}$ oxyhydroxide fraction in this core (black filled circles). Individual $\mathrm{Nd}$ isotope data are presented in Tables 3 to 5 . The modern NADW $\varepsilon_{\mathrm{Nd}}$, as measured by Piepgras and Wasserburg (1987) close to the Blake Ridge (cf. Fig. 1), is shown in grey box. Blue arrows in lower panel indicate absolute age tie points published in Keigwin (2004).

Figure 6. Combined $\mathrm{Nd}$ isotope evolution of core 51GGC (1790 m) and 12JPC (4250 $\mathrm{m})$, plotted against age. Also shown is the Northern Greenland $\delta^{18} \mathrm{O}$ NGRIP record of (Andersen et al., 2004a) (upper panel), as well as the $\mathrm{Nd}$ isotope trends seen for the detrital fraction in the sediments (middle panel). The modern NADW $\varepsilon_{\mathrm{Nd}}$, as measured by (Piepgras and Wasserburg, 1987), is indicated in grey box. 
Figure 7. Schematic simplified cross section through the NE American continental shelf and continental rise towards the open North Atlantic. Sediments with pre-acquired Fe-Mn oxyhydroxide coating are prone to re-suspension on the North American shelf, as indicated by the trajectory of the vigorously flowing Florida Current, and sediment is exported into depths where NADW prevails. The filled black dot marks the approximate position of the major flow axis of the WBUC today. MLSW: Mid-latitudinal warm surface water. See text for discussion.

Table 1. Collector array for the Nu Plasma MC-ICPMS used for the U/Th analyses in Zürich. Simultaneous measurements of the different $U$ and Th isotopes were carried out on Faraday collectors (F), and two secondary ion multipliers (IC0 and IC2). Numbers in brackets refer to the number of mass units (amu) away from the Axial Faraday collector.

Table 2. Individual results for the ${ }^{230} \mathrm{Th}_{\mathrm{xs}}$ analyses of core $51 \mathrm{GGC}$ presented in Figures 2 and 5. Associated errors represent the $2 \sigma$ internal analytical error, quoted to two significant figures. All isotope ratios were corrected offline for the contribution from the trace amounts of natural ${ }^{238} \mathrm{U},{ }^{235} \mathrm{U},{ }^{234} \mathrm{U},{ }^{232} \mathrm{Th}$ and ${ }^{230} \mathrm{Th}$ present in the artificial spike tracer. Linearly interpolated half mass zeros were subtracted from all ion beams to account for the peak tailing contributions beneath the minor ion beams from the large beams of the major isotopes ${ }^{238} \mathrm{U}$ and ${ }^{232} \mathrm{Th}$. Abundance sensitivity was $<5 \mathrm{ppm}$ amu ${ }^{-1}$ during the measurements (cf. Andersen et al., 2004b). Monitored ${ }^{232} \mathrm{ThH}^{+}$formation rate was below $5 \mathrm{ppm}$ of the ${ }^{232} \mathrm{Th}$ ion beam and subtracted from the ${ }^{233} \mathrm{U}$ ion beam. Sedimentation rates were calculated from Keigwin (2004). Secular equilibrium and CRM $145 \mathrm{U}$ standard solution ${ }^{234} \mathrm{U}^{238} \mathrm{U}$ are taken from Cheng et al. (2000), $\lambda^{232} \mathrm{Th}$ is taken from Holden (1990). The activities of the measured ${ }^{230} \mathrm{Th}_{\mathrm{xs}}$ were decay-corrected to the time of deposition of the sediment using $\lambda^{230}$ Th of Cheng et al. (2000).

Table 3. Individual $\mathrm{Nd}$ isotope results for the Fe-Mn oxyhydroxide fraction of core-top and LGM sediments presented in Figure 3 including the $2 \sigma$ internal errors. 
Table 4. Individual $\mathrm{Nd}$ isotope results for the Fe-Mn oxyhydroxide fraction for sediments of core 51GGC, $31 \mathrm{GGC}$ and 12JPC presented in Figures 4, 5 and 6 including the $2 \sigma$ internal errors. Samples denoted [a] have been leached, purified and measured at the University of Bristol, UK. The extraction and purification procedure was identical to the remaining samples. Measurements were carried out on a Thermo Finnigan Neptune MC-ICPMS following the machine-induced mass bias correction scheme of Vance and Thirlwall (2002). Calendar ages given for core 12JPC are approximate since only three radiocarbon dates are available and the sedimentation rate changed significantly in the course of the Younger Dryas.

Table 5. Individual $\mathrm{Nd}$ isotope results for the Fe-Mn oxyhydroxide and the detrital fractions for sediments of core 51GGC and 12JPC presented in Figures 4b, 5 and 6 including the $2 \sigma$ internal errors. All but two (i.e., 51GGC-270; 51GGC-316) Fe-Mn oxyhydroxide coating results shown here represent additional duplicates to samples plotted in Table 4. 


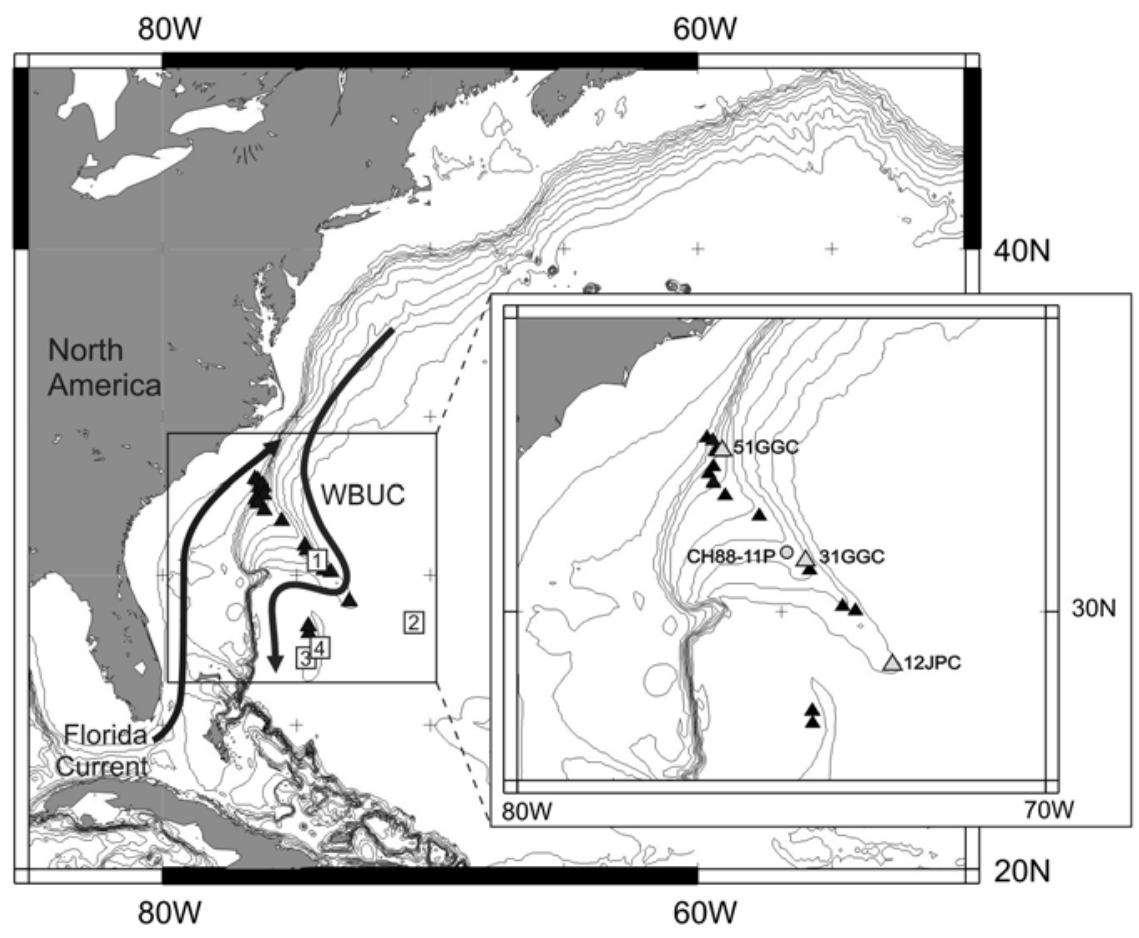

Figure 1. 

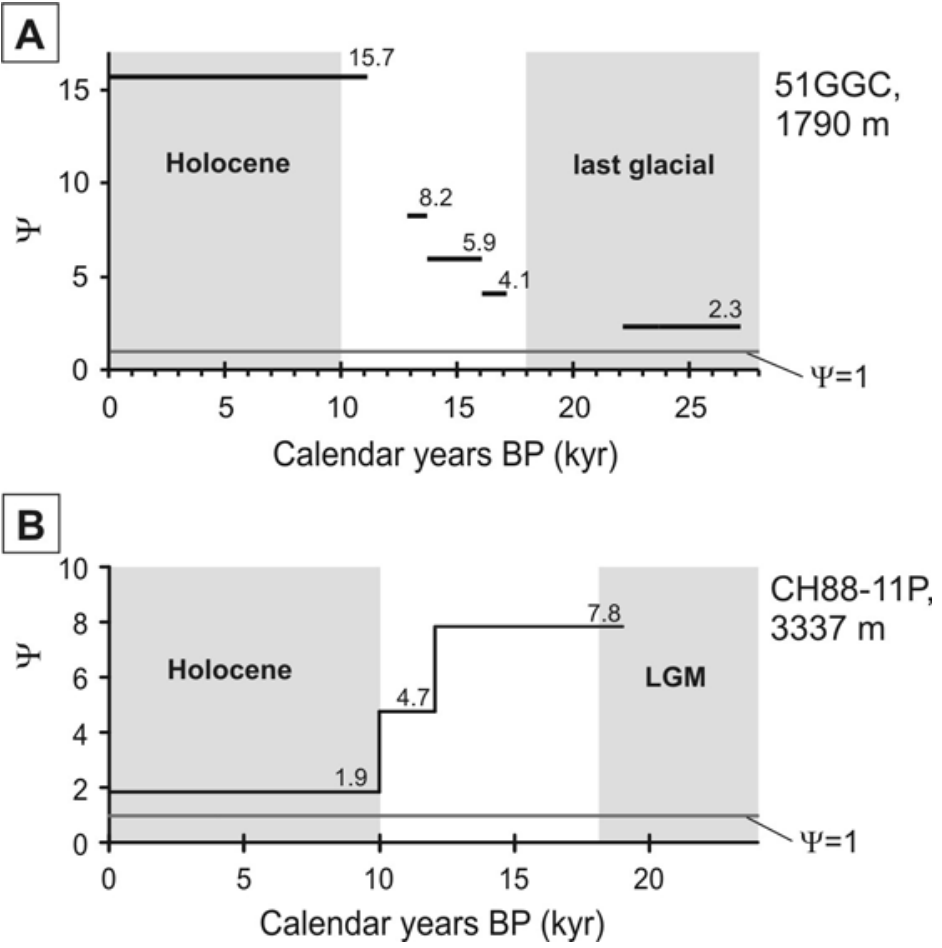

Figure 2. 


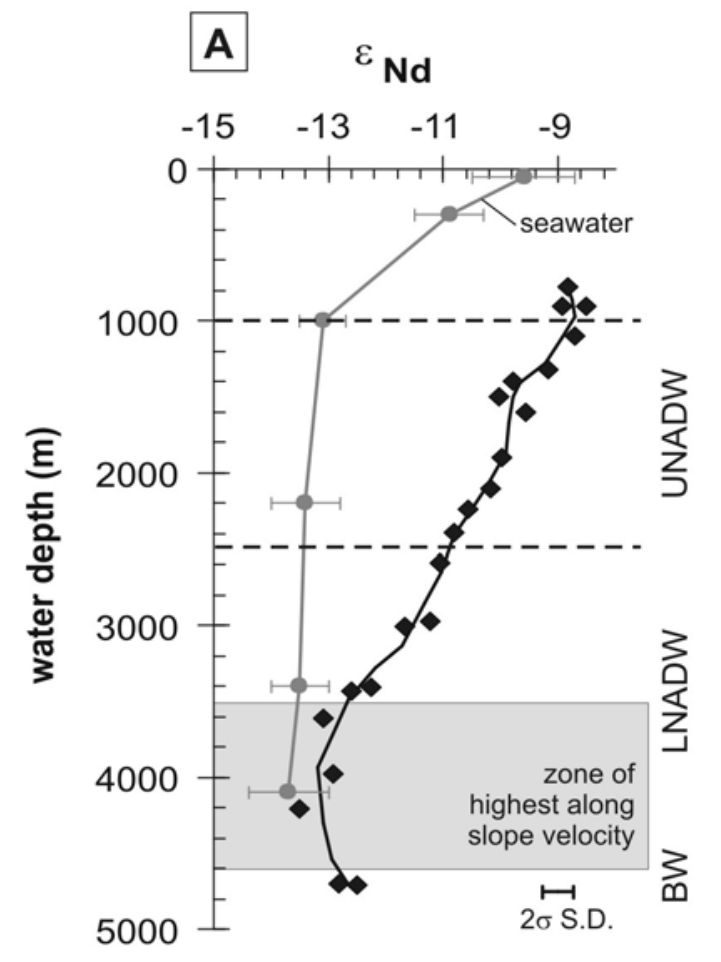

Holocene

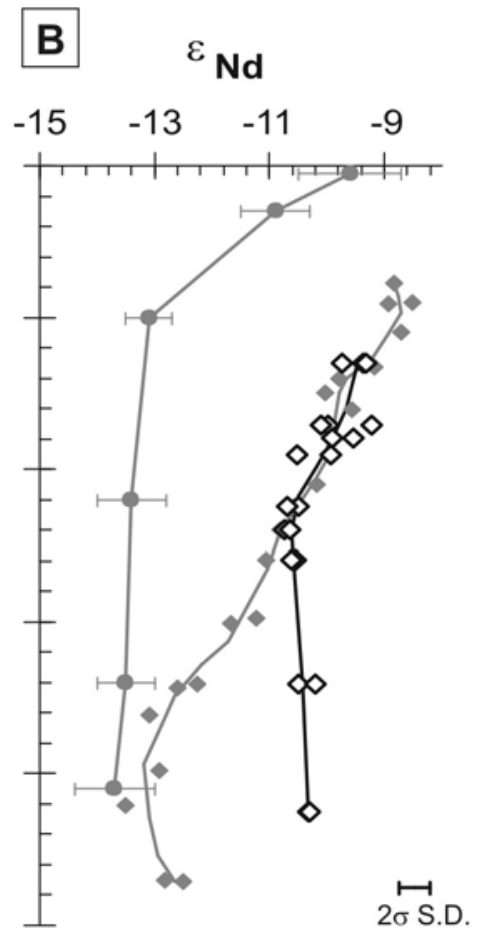

Last Glacial Maximum

Figure 3. 
A

$31 \mathrm{GGC}, 3410 \mathrm{~m}$

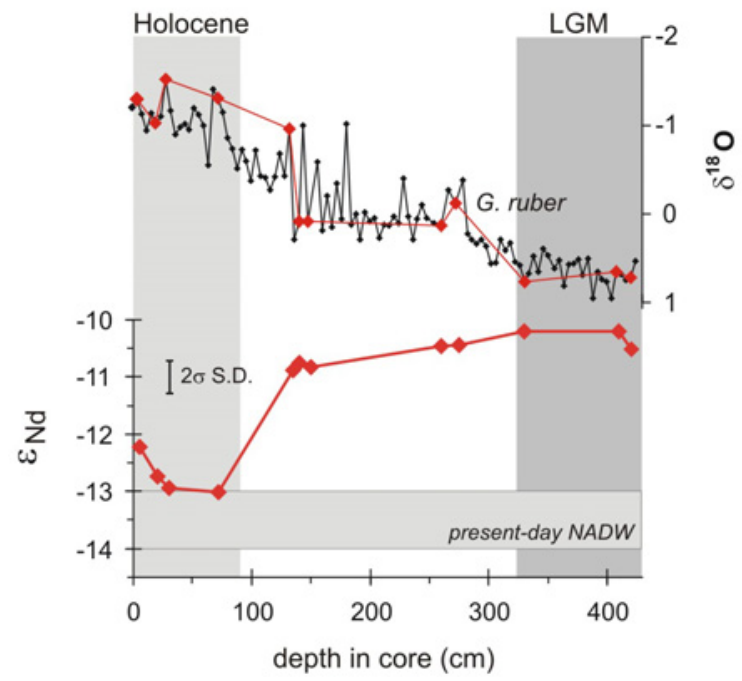

B

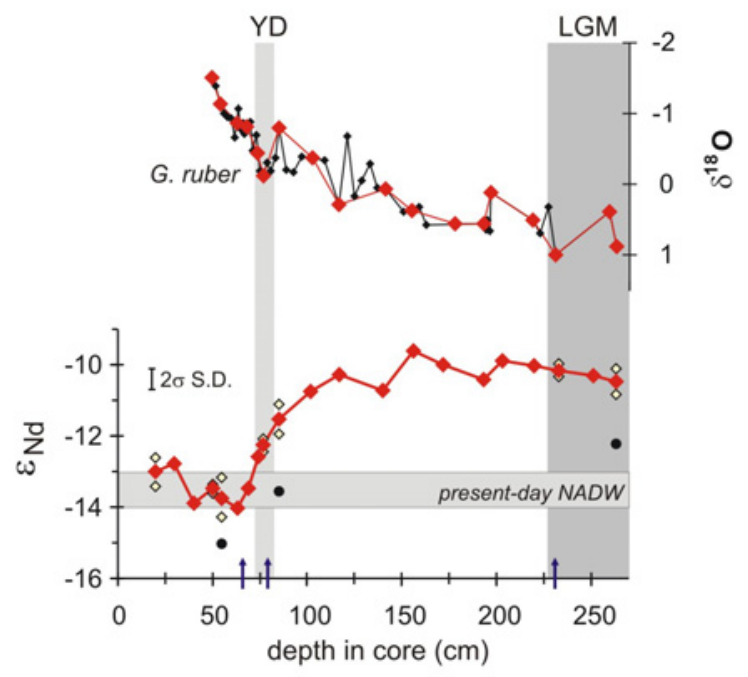

Figure 4. 


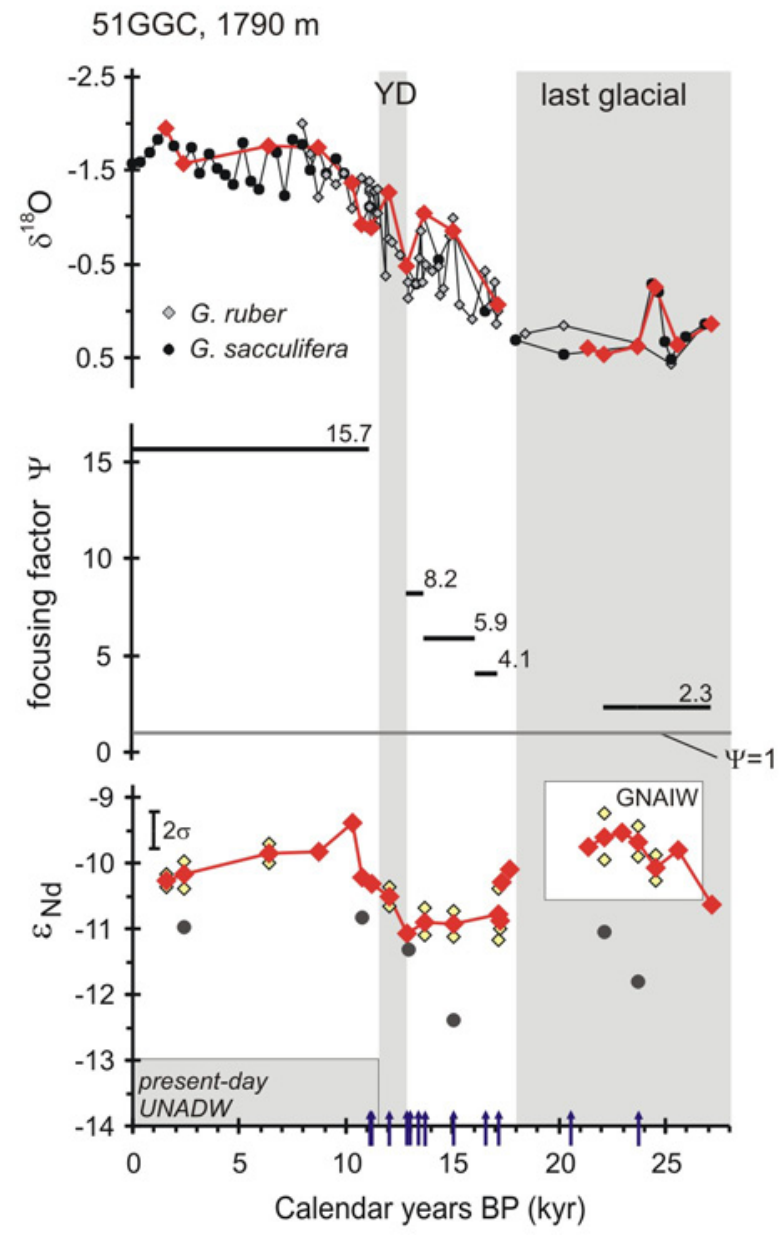

Figure 5. 

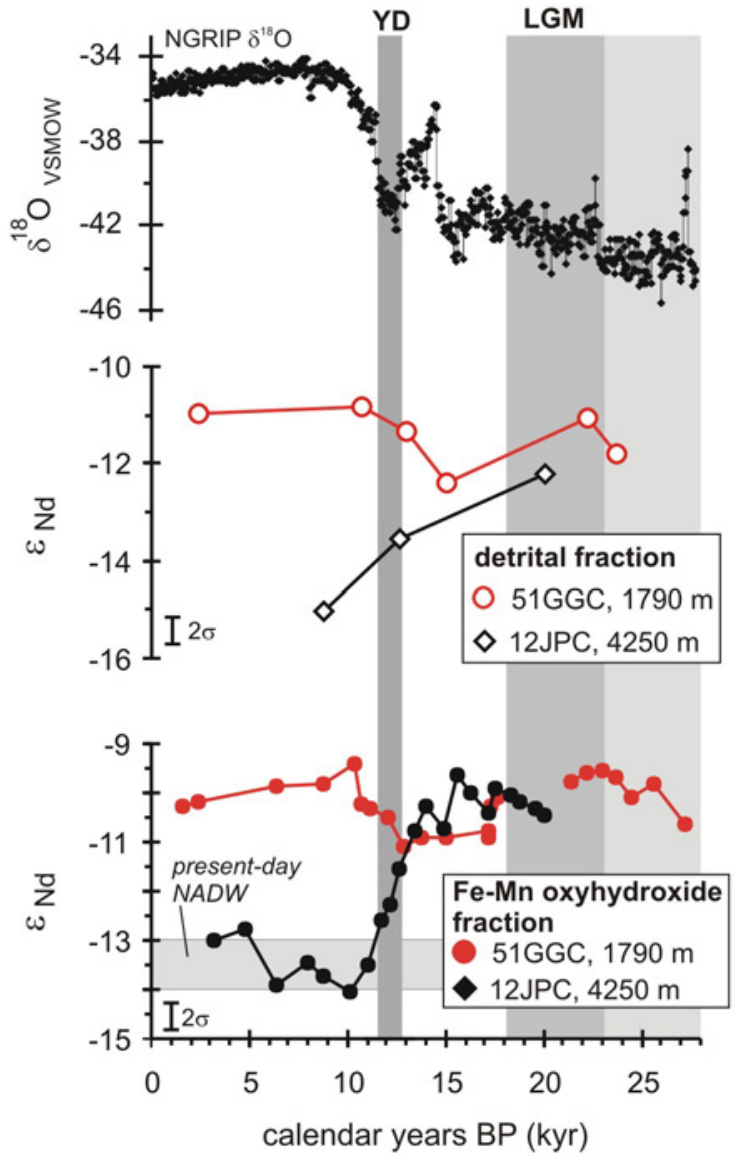

Figure 6. 


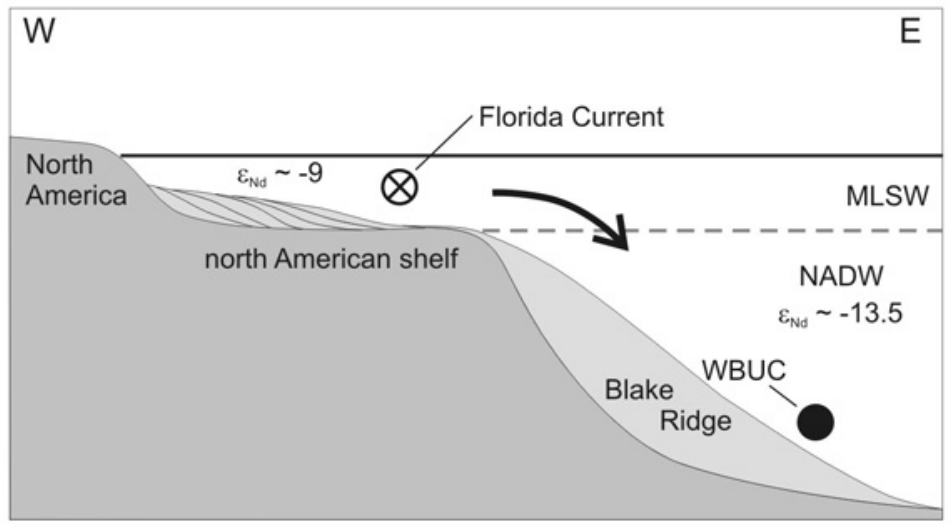

Figure 7. 
Table 1. Collector array for the Nu Plasma MC-ICPMS (Nu1) at ETH in Zürich. \begin{tabular}{llllllllll}
$\mathrm{F}(+2)$ & $\mathrm{F}(+1)$ & $\mathrm{F}(\mathrm{Ax})$ & $\mathrm{F}(-1)$ & $\mathrm{F}(-2)$ & $\mathrm{IC} 0(-3)$ & $\mathrm{F}(-4)$ & $\mathrm{IC} 1(-5)$ & $\mathrm{F}(-6)$ & IC2(-7) \\
\hline
\end{tabular}

Step 1

${ }^{238} \mathrm{U}$

${ }^{235} \mathrm{U}$

${ }^{234} \mathrm{U}$

${ }^{230} \mathrm{Th}$

Step 2

${ }^{238} \mathrm{U}$

${ }^{235} \mathrm{U}$

${ }^{233} \mathrm{U} \quad{ }^{232} \mathrm{Th}$

${ }^{229} \mathrm{Th}$ 
Table 2. ${ }^{230} \mathrm{Th}_{x \mathrm{~s}}$ results of core 51GGC, $1790 \mathrm{~m}$

\begin{tabular}{|c|c|c|c|c|c|c|c|c|c|}
\hline $\begin{array}{l}\text { Depth in core } \\
(\mathrm{cm})\end{array}$ & $\begin{array}{c}\text { Calendar age } \\
(\mathrm{ka} \mathrm{BP})\end{array}$ & $\left.{ }^{238} \mathrm{U}\right|^{232} \mathrm{Th}$ & $\begin{array}{c}\mathbf{A}\left({ }^{230} \mathrm{Th}\right) \\
(\mathrm{dpm} / \mathrm{g})\end{array}$ & $\begin{array}{c}\mathbf{A}\left({ }^{232} \mathrm{Th}\right) \\
(\mathrm{dpm} / \mathrm{g})\end{array}$ & $\begin{array}{c}\mathbf{A}\left({ }^{230} \mathrm{Th}_{\mathrm{xs}}\right)_{\text {meas }} \\
(\mathrm{dpm} / \mathrm{g})\end{array}$ & $\begin{array}{c}\mathrm{A}\left({ }^{230} \mathrm{Th}_{\mathrm{xs}}\right)_{\text {decay-corr }} \\
(\mathrm{dpm} / \mathrm{g})\end{array}$ & $\begin{array}{c}\text { sedimentation } \\
\text { rates } \\
(\mathrm{cm} / \mathrm{kyr}) \\
\end{array}$ & $\begin{array}{c}\text { flux/kyr } \\
(\mathrm{dpm} / \mathrm{g})^{\star}(\mathrm{cm} / \mathrm{kyr}) \\
\end{array}$ & $\Psi$ \\
\hline 160 & 6.36 & $0.93390 \pm 54$ & 3.263 & 1.256 & 2.509 & 2.660 & 25.2 & 66.9 & 14.2 \\
\hline 220 & 8.75 & $0.68364 \pm 24$ & 3.923 & 1.607 & 2.958 & 3.205 & 25.2 & 80.6 & 17.1 \\
\hline 316 & 13.0 & $0.75168 \pm 210$ & 2.119 & 0.962 & 1.542 & 1.737 & 22.3 & 38.7 & 8.2 \\
\hline 350 & 15.0 & $0.45632 \pm 26$ & 2.775 & 1.959 & 1.600 & 1.836 & 15.1 & 27.7 & 5.9 \\
\hline 370 & 17.2 & $0.58286 \pm 41$ & 2.823 & 1.835 & 1.722 & 2.015 & 9.5 & 19.1 & 4.1 \\
\hline 390 & 22.1 & $0.58770 \pm 220$ & 2.173 & 1.257 & 1.419 & 1.738 & 6.3 & 11.0 & 2.3 \\
\hline 405 & 24.5 & $0.39025 \pm 38$ & 2.590 & 2.115 & 1.321 & 1.653 & 6.3 & 10.5 & 2.2 \\
\hline 422 & 27.2 & $0.57571 \pm 29$ & 2.315 & 1.648 & 1.326 & 1.701 & 6.3 & 10.8 & 2.3 \\
\hline
\end{tabular}


Table 3a. Nd isotope results, Fe-Mn oxyhydroxide fractions, core-top samples

\begin{tabular}{|c|c|c|c|c|c|}
\hline Core & $\begin{array}{c}\text { Water } \\
\text { depth }(\mathrm{m})\end{array}$ & latitude N & longitude W & ${ }^{143} \mathrm{Nd} /{ }^{144} \mathrm{Nd}$ & $\varepsilon_{\mathrm{Nd}}$ \\
\hline GGC-68 & 775 & $32^{\circ} 56.58^{\prime}$ & $76^{\circ} 33.10^{\prime}$ & $0.512186 \pm 6$ & -8.8 \\
\hline JPC-63 & 900 & $32^{\circ} 59.30^{\prime}$ & $76^{\circ} 24.42^{\prime}$ & $0.512186 \pm 6$ & -8.8 \\
\hline JPC-63 & duplicate & & & $0.512190 \pm 19$ & -8.7 \\
\hline GGC-62 & 906 & $32^{\circ} 59.36^{\prime}$ & $76^{\circ} 24.02^{\prime}$ & $0.512181 \pm 9$ & -8.9 \\
\hline GGC-60 & 1100 & $32^{\circ} 59.41^{\prime}$ & $76^{\circ} 20.06^{\prime}$ & $0.512192 \pm 8$ & -8.7 \\
\hline GGC-57 & 1323 & $32^{\circ} 57.78^{\prime}$ & $76^{\circ} 17.80^{\prime}$ & $0.512168 \pm 6$ & -9.2 \\
\hline GGC-56 & 1400 & $32^{\circ} 56.34^{\prime}$ & $76^{\circ} 17.74^{\prime}$ & $0.512137 \pm 19$ & -9.8 \\
\hline GGC-54 & 1495 & $32^{\circ} 56.07^{\prime}$ & $76^{\circ} 16.54^{\prime}$ & $0.512123 \pm 5$ & -10.0 \\
\hline GGC-53 & 1605 & $32^{\circ} 55.92^{\prime}$ & $76^{\circ} 14.79^{\prime}$ & $0.512148 \pm 6$ & -9.6 \\
\hline GGC-50 & 1903 & $32^{\circ} 45.16^{\prime}$ & $76^{\circ} 14.18^{\prime}$ & $0.512127 \pm 7$ & -10.0 \\
\hline GGC-64 & 2101 & $32^{\circ} 44.51^{\prime}$ & $76^{\circ} 07.61^{\prime}$ & $0.512116 \pm 5$ & -10.2 \\
\hline PG-1 & 2243 & $32^{\circ} 22.51^{\prime}$ & $76^{\circ} 22.96^{\prime}$ & $0.512097 \pm 10$ & -10.6 \\
\hline PG-2 & 2394 & $32^{\circ} 13.56^{\prime}$ & $76^{\circ} 17.37^{\prime}$ & $0.512084 \pm 7$ & -10.8 \\
\hline GGC-43 & 2590 & $32^{\circ} 01.02^{\prime}$ & $76^{\circ} 04.03^{\prime}$ & $0.512071 \pm 6$ & -11.1 \\
\hline GGC-39 & 2975 & $31^{\circ} 40.13^{\prime}$ & $75^{\circ} 24.90^{\prime}$ & $0.512062 \pm 6$ & -11.2 \\
\hline JPC-36 & 3007 & $31^{\circ} 21.54^{\prime}$ & $75^{\circ} 03.71^{\prime}$ & $0.512040 \pm 15$ & -11.7 \\
\hline GGC-30 & 3433 & $30^{\circ} 44.03^{\prime}$ & $74^{\circ} 28.09^{\prime}$ & $0.511992 \pm 7$ & -12.6 \\
\hline GGC-32 & 3615 & $30^{\circ} 48.05^{\prime}$ & $74^{\circ} 47.84^{\prime}$ & $0.511966 \pm 7$ & -13.1 \\
\hline GGC-29 & 3978 & $30^{\circ} 01.07^{\prime}$ & $73^{\circ} 36.22^{\prime}$ & $0.511976 \pm 7$ & -12.9 \\
\hline GGC-28 & 4211 & $30^{\circ} 05.88^{\prime}$ & $73^{\circ} 50.21^{\prime}$ & $0.511945 \pm 6$ & -13.5 \\
\hline GGC-21 & 4705 & $28^{\circ} 14.75^{\prime}$ & $74^{\circ} 24.62^{\prime}$ & $0.511980 \pm 8$ & -12.8 \\
\hline JPC-22 & 4712 & $28^{\circ} 14.79^{\prime}$ & $74^{\circ} 24.42^{\prime}$ & $0.511998 \pm 21$ & -12.5 \\
\hline
\end{tabular}

Table 3b. Nd isotope results, Fe-Mn oxyhydroxide fractions, LGM samples

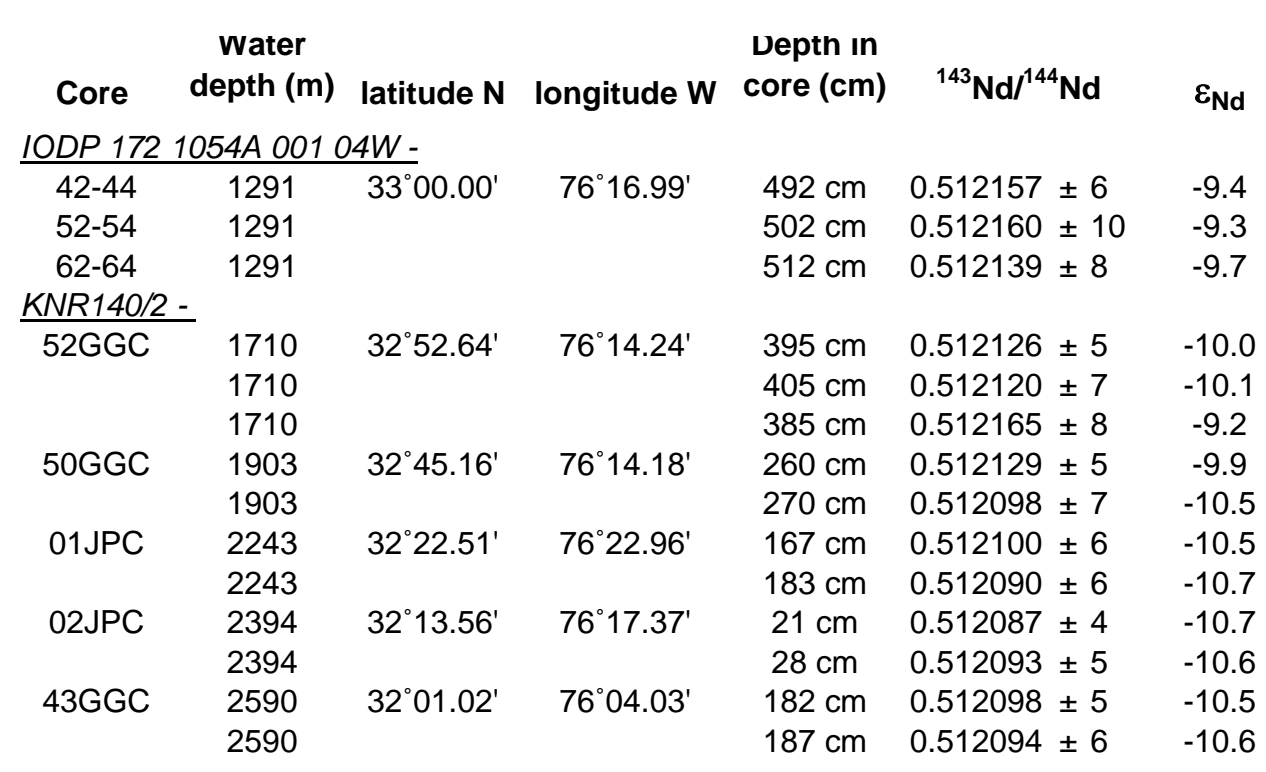


Table 4. Nd isotope results, Fe-Mn oxyhydroxide fractions

\begin{tabular}{|c|c|c|c|c|}
\hline \multirow{2}{*}{\multicolumn{2}{|c|}{$\begin{array}{c}\text { Depth in core (cm) Calendar Age (ka) } \\
51 G G C, 1790 \mathrm{~m}\left(32^{\circ} 47.04^{\prime} \mathrm{N}, 76^{\circ} 17.18^{\prime} \mathrm{W}\right)\end{array}$}} & \multicolumn{2}{|c|}{${ }^{143} \mathrm{Nd} /{ }^{144} \mathrm{Nd}$} & \multirow[t]{2}{*}{$\varepsilon_{\mathrm{Nd}}$} \\
\hline & & & & \\
\hline 40 & 1.59 & 0.512107 & 5 & -10.4 \\
\hline 40 & duplicate & 0.512117 & \pm 5 & -10.2 \\
\hline 60 & 2.39 & 0.512106 & 4 & -10.4 \\
\hline 160 & 6.36 & 0.512126 & 6 & -10.0 \\
\hline 160 & duplicate & 0.512140 & \pm 6 & -9.7 \\
\hline 220 & 8.75 & 0.512135 & \pm 6 & -9.8 \\
\hline 260 & 10.34 & 0.512157 & \pm 8 & -9.4 \\
\hline 290 & 11.20 & 0.512109 & \pm 6 & -10.3 \\
\hline 300 & 12.06 & 0.512092 & \pm 5 & -10.7 \\
\hline 300 & duplicate & 0.512107 & \pm 8 & -10.4 \\
\hline 310 & 12.89 & 0.512070 & \pm 6 & -11.1 \\
\hline 330 & 13.72 & 0.512069 & 5 & -11.1 \\
\hline 330 & duplicate & 0.512091 & \pm 6 & -10.7 \\
\hline 350 & 15.0 & 0.512068 & 5 & -11.1 \\
\hline 370 & 17.2 & 0.512065 & \pm 5 & -11.2 \\
\hline 370 & duplicate & 0.512106 & 5 & -10.4 \\
\hline 371 & 17.2 & 0.512074 & \pm 6 & -11.0 \\
\hline 371 & duplicate & 0.512085 & \pm 5 & -10.8 \\
\hline 373 & 17.3 & 0.512110 & \pm 6 & -10.3 \\
\hline 378 & 17.7 & 0.512121 & \pm 8 & -10.1 \\
\hline 385 & 21.4 & 0.512137 & 7 & -9.8 \\
\hline 390 & 22.1 & 0.512128 & \pm 8 & -10.0 \\
\hline 395 & 22.9 & 0.512149 & \pm 10 & -9.5 \\
\hline 400 & 23.7 & 0.512130 & \pm 7 & -9.9 \\
\hline 405 & 24.5 & 0.512111 & \pm 8 & -10.3 \\
\hline 405 & duplicate & 0.512132 & \pm 6 & -9.9 \\
\hline 412 & 25.6 & 0.512135 & \pm 7 & -9.8 \\
\hline 422 & 27.2 & 0.512093 & \pm 7 & -10.6 \\
\hline
\end{tabular}

31GGC, $3410 \mathrm{~m}\left(30^{\circ} 54.13^{\prime} \mathrm{N}, 74^{\circ} 32.69^{\prime} \mathrm{W}\right)$

core-top
20
30
72
135
140
150
260
275
330
410
420

$\begin{array}{llll}0.512011 & \pm & 25 & -12.2 \\ 0.511985 & \pm & 5 & -12.7 \\ 0.511974 & \pm & 5 & -12.9 \\ 0.511971 & \pm & 5 & -13.0 \\ 0.512080 & \pm & 8 & -10.9 \\ 0.512087 & \pm & 5 & -10.8 \\ 0.512083 & \pm & 6 & -10.8 \\ 0.512101 & \pm & 5 & -10.5 \\ 0.512103 & \pm & 6 & -10.4 \\ 0.512115 & \pm & 5 & -10.2 \\ 0.512115 & \pm & 5 & -10.2 \\ 0.512099 & \pm & 5 & -10.5\end{array}$


Table 4 - continued

\begin{tabular}{|c|c|c|c|c|c|}
\hline Depth in core $(\mathrm{cm})$ & $\begin{array}{c}\text { Approximate } \\
\text { calendar Age (ka) }\end{array}$ & \multicolumn{2}{|c|}{${ }^{143} \mathrm{Nd} /{ }^{144} \mathrm{Nd}$} & \multicolumn{2}{|l|}{$\varepsilon_{\mathrm{Nd}}$} \\
\hline \multicolumn{6}{|c|}{$12 \mathrm{JPC}, 4250 \mathrm{~m}\left(29^{\circ} 04.48^{\prime} \mathrm{N}, 72^{\circ} 53.90^{\prime} \mathrm{W}\right)$} \\
\hline \multirow[t]{2}{*}{20} & 3.20 & 0.511951 & \pm 6 & -13.4 & \\
\hline & duplicate & 0.511992 & \pm 4 & -12.6 & \\
\hline 30 & 4.81 & 0.511984 & \pm 6 & -12.8 & \\
\hline 40 & 6.41 & 0.511926 & \pm 5 & -13.9 & [a] \\
\hline \multirow{2}{*}{50} & 8.01 & 0.511954 & \pm 6 & -13.3 & \\
\hline & duplicate & 0.5119408 & \pm 5 & -13.6 & [a] \\
\hline \multirow[t]{2}{*}{55} & 8.81 & 0.511907 & \pm 8 & -14.3 & \\
\hline & duplicate & 0.511930 & \pm 6 & -13.8 & [a] \\
\hline 63 & 10.09 & 0.5119185 & \pm 7 & -14.0 & [a] \\
\hline 69 & 11.00 & 0.511947 & \pm 6 & -13.5 & \\
\hline 74 & 11.71 & 0.5119924 & \pm 4 & -12.6 & [a] \\
\hline \multirow[t]{2}{*}{77} & 12.14 & 0.512001 & \pm 6 & -12.4 & \\
\hline & duplicate & 0.5120182 & \pm 4 & -12.1 & [a] \\
\hline 85 & 12.67 & 0.512025 & \pm 6 & -12.0 & \\
\hline 102 & 13.38 & 0.512087 & \pm 6 & -10.8 & \\
\hline 117 & 14.00 & 0.512111 & \pm 5 & -10.3 & \\
\hline 140 & 14.95 & 0.512088 & \pm 5 & -10.7 & \\
\hline 156 & 15.62 & 0.512145 & \pm 5 & -9.6 & \\
\hline 172 & 16.28 & 0.512126 & \pm 6 & -10.0 & \\
\hline 193 & 17.15 & 0.512104 & \pm 5 & -10.4 & \\
\hline 203 & 17.57 & 0.512130 & \pm 6 & -9.9 & \\
\hline 220 & 18.27 & 0.512124 & \pm 7 & -10.0 & \\
\hline 233 & 18.73 & 0.512108 & \pm 6 & -10.3 & \\
\hline 233 & duplicate & 0.512126 & \pm 5 & -10.0 & \\
\hline 251 & 19.56 & 0.512110 & \pm 4 & -10.3 & \\
\hline 263 & 20.05 & 0.512083 & \pm 7 & -10.8 & \\
\hline
\end{tabular}


Table 5. Samples for which both the coatings and the detrital fraction were analysed

\begin{tabular}{|c|c|c|c|c|c|}
\hline \multirow{2}{*}{$\begin{array}{r}\text { Core } \\
51 G G C\end{array}$} & \multirow{2}{*}{$\begin{array}{c}\text { Depth in core (cm) } \\
60\end{array}$} & \multirow{3}{*}{$\begin{array}{l}\text { sample type } \\
\text { coating } \\
\text { detrital }\end{array}$} & \multicolumn{2}{|c|}{${ }^{143} \mathrm{Nd} /{ }^{144} \mathrm{Nd}$} & \multirow{2}{*}{$\begin{array}{c}\varepsilon_{\mathbf{N d}} \\
-10.0\end{array}$} \\
\hline & & & 0.512127 & \pm 12 & \\
\hline & & & 0.512076 & \pm 10 & -11.0 \\
\hline \multirow[t]{2}{*}{$51 G G C$} & 270 & coating & 0.512114 & \pm 10 & -10.2 \\
\hline & & detrital & 0.512083 & \pm 9 & -10.8 \\
\hline \multirow[t]{2}{*}{$51 G G C$} & 316 & coating & 0.512109 & \pm 10 & -10.3 \\
\hline & & detrital & 0.512057 & \pm 10 & -11.3 \\
\hline \multirow[t]{2}{*}{$51 G G C$} & 350 & coating & 0.512088 & \pm 11 & -10.7 \\
\hline & & detrital & 0.512003 & \pm 8 & -12.4 \\
\hline \multirow[t]{2}{*}{$51 G G C$} & 390 & coating & 0.512164 & \pm 9 & -9.3 \\
\hline & & detrital & 0.512071 & \pm 10 & -11.1 \\
\hline \multirow[t]{2}{*}{$51 G G C$} & 400 & coating & 0.512154 & \pm 9 & -9.4 \\
\hline & & detrital & 0.512033 & \pm 9 & -11.8 \\
\hline \multirow[t]{2}{*}{ 12JPC } & 55 & coating & 0.511963 & \pm 7 & -13.2 \\
\hline & & detrital & 0.511868 & \pm 8 & -15.0 \\
\hline \multirow[t]{2}{*}{ 12JPC } & 85 & coating & 0.512069 & \pm 9 & -11.1 \\
\hline & & detrital & 0.511943 & \pm 9 & -13.6 \\
\hline \multirow[t]{2}{*}{ 12JPC } & 263 & coating & 0.512119 & \pm 9 & -10.1 \\
\hline & & detrital & 0.512012 & \pm 7 & -12.2 \\
\hline
\end{tabular}

